\title{
Non-audit services and financial reporting quality: evidence from 1978 to 1980
}

\section{Citation}

Koh, Kevin, Shiva Rajgopal, and Suraj Srinivasan. "Non-Audit Services and Financial Reporting Quality: Evidence from 1978-1980." Review of Accounting Studies 18, no. 1 (March 2013): 1-33.

\section{Published Version}

http://link.springer.com/article/10.1007/s11142-012-9187-6

\section{Permanent link}

http://nrs.harvard.edu/urn-3:HUL.InstRepos:29660920

\section{Terms of Use}

This article was downloaded from Harvard University's DASH repository, and is made available under the terms and conditions applicable to Open Access Policy Articles, as set forth at http:// nrs.harvard.edu/urn-3:HUL.InstRepos:dash.current.terms-of-use\#OAP

\section{Share Your Story}

The Harvard community has made this article openly available.

Please share how this access benefits you. Submit a story.

Accessibility 


\title{
Non-Audit Services and Financial Reporting Quality: Evidence from 1978-1980
}

\author{
Kevin Koh \\ Nanyang Technological University, Singapore \\ Email: kevkohwl@pmail.ntu.edu.sg \\ Shiva Rajgopal \\ Schaefer Chaired Professor of Accounting \\ Goizueta Business School, Emory University \\ Email: shivaram.rajgopal@emory.edu \\ and \\ Suraj Srinivasan \\ Harvard Business School \\ Email: ssrinivasan@hbs.edu
}

April 19, 2011

\begin{abstract}
:
We provide evidence on the long standing concern on auditor conflicts of interest from providing non-audit services (NAS) to audit clients by using rarely explored NAS fee data from 1978-80. Using this earlier setting, we find cross-sectional evidence of improved earnings quality when auditors provide NAS, especially those related to information services. This is consistent with better audit quality from knowledge spillovers due to the joint offering of audit and consulting services. Events related to the repeal of these NAS disclosures in 1982 are associated with a small positive stock price reaction suggesting no adverse economic consequences of withdrawing NAS disclosures. Further, following the repeal of disclosure requirements we find no change in the earnings quality of client firms. In sum, data drawn from an earlier time period suggest that auditors' reputational incentives, possible synergies and knowledge transfers imply that NAS offered by audit firms can be associated with improved audit and reporting quality in client firms.
\end{abstract}

We thank our respective schools for financial support. We thank Ray Ball, Phil Berger, Mark DeFond, Aiyesha Dey, Bill Kinney, Doug Skinner, Hun-Tong Tan and workshop participants at Nanyang Technological University, the International Symposium on Audit Research conference at the University of Southern California, 2008 American Accounting Association annual meeting, and 2009 European Accounting Association Annual Congress for helpful comments. We are grateful to the staff at the University of Chicago Regenstein Library, Northwestern University Library and the Chicago Public Library (Main Branch) for assisting in the use of their microfiche collection of proxy statements. We thank Mark Maffet for his excellent research assistance. All errors are ours. 


\section{Non-Audit Services and Financial Reporting Quality: Evidence from 1978-1980}

\subsection{Introduction}

In this paper, we examine if non-audit services (NAS) fees paid to one's auditor are associated with lower quality financial reporting using data from 1978-80. This time period provides a substantially different auditing and business regime than recent years when most research is based. Thus, we provide an early history analysis of a long standing regulatory concern that NAS fees create an economic dependence that causes the auditor to acquiesce to the client's wishes in financial reporting thus reducing audit quality (Metcalf Committee Staff Study, 1977; SEC 1978, SEC 2000, POB 2000). A related concern is that NAS fees may impair investor perceptions of auditor independence (Levitt 1998). This presumption has led to banning some NAS by statute and regulation, regulation mandating disclosure of fees from such services and prior approval of services by independent directors, and most recently to the Sarbanes Oxley Act of 2002 (SOX) banning the provision of most NAS to audit clients. However, there are economic benefits to combining NAS with audit services. Knowledge spillovers between NAS and auditing allow auditors greater insights into their clients, improving audit quality and making auditors efficient providers of NAS (Cohen Commission 1978; Simunic 1984). Moreover, reputational concerns and litigation risk provide incentives for auditors to maintain their independence and check deterioration in audit quality (Watts and Zimmerman 1983).

In June 1978, the SEC issued Accounting Series Release (ASR) No. 250 (SEC 1978) that required, for the first time, proxy statement disclosure of non-audit fee information. ASR No. 250 was rescinded effective February 1982. The (fiscal) years 1978-1980 therefore represent the only time period, other than during a brief period in 2001 (for FY 2000), when companies were required to disclose fees for NAS paid to their auditors before most NAS was prohibited by SOX.

The 1978-80 setting has unique institutional characteristics that allow for powerful tests to identify costs and benefits of providing NAS for the following reasons (we expand on these in 
section 2.2). In 1972, the AICPA removed the ban on competitive bidding from its Code of Ethics under pressure from the Department of Justice (DOJ) (Zeff, 2003; Kinney, 2005). By 1979, the DOJ and the Federal Trade Commission (FTC) had pressured the AICPA to drop its rules prohibiting direct, uninvited solicitation, competitive bidding, and informational advertising. These rules had "provided a measure of price protection and reduced cost pressures among audit firms.” (Kinney 2005, pp. 91). Kinney (1988) notes that the changes, starting in 1972 created an increasingly competitive audit market and are described as "cut-throat” and as one with "vigorous price cutting” by market observers quoted in Zeff (2003). Consistent with this, Maher et al, (1992) document a significant decrease in audit fees between 1977 and 1981. Further, the audit industry was less concentrated and hence more competitive in 1978-80 compared to later years. The greater price competition increased the threats to independence by providing NAS.

Second, consulting services were a more integral part of the audit firms in the 1970's in contrast to the relatively independent and sometimes antagonistic relationship between auditing and consulting units in the late 1990's increasing the likelihood that auditors accommodated clients due to NAS fees (Francis, 2006). ${ }^{1}$ Third, information systems (IS) consulting was the biggest component of NAS during 1978-80 (25\% in our sample). ${ }^{2}$ Information systems related fees (ISFEE) represent the largest component of NAS in our sample and are of particular concern to regulators because they create a situation where "auditors are functioning as management, or may result in an auditor auditing his or her own work” (SEC 2000). However, this is also the area with the largest possible spillover benefits - audit firms argue that IS consulting helps improve financial reporting quality by improving their access to technology, expanding their understanding of the clients business, and aiding personnel recruiting efforts (SEC 2000).

\footnotetext{
${ }^{1}$ Andersen Consulting was engaged in a bitter dispute with Arthur Andersen \& Co since 1997 ending in a separation decision in August 2000. Other big auditors also separated their consulting divisions in early 2000s (Ernst \& Young sold consulting business to Cap Gemini in 2000, PwC sold its consulting business to IBM in 2002, and KPMG consulting spun-off as Bearing Point in January 2000)

${ }^{2}$ In contrast Kinney, Palmrose and Scholz (2004) find that only 5\% of public firms bought any information system related services from their auditors by the late 1990s.
} 
Consistent with the SEC's formulation and prior work, we use two proxies for the strength of the economic bond between the auditor and their clients: (i) the ratio of non-audit fees to total fees (NAS); (ii) the extent of fees paid for IS consulting. ${ }^{3}$ We employ three proxies for the quality of financial reporting: (i) the magnitude of absolute discretionary accruals; (ii) the likelihood of reporting a small earnings surprise; and (iii) earnings informativeness for stock returns. Concerns about NAS relate to both loss of independence in fact (resulting from the state of mind of the auditor) and loss of independence in appearance (in the mind of a third party e.g., an investor). We test for both these constructs - the first two measures above relate to the effect of actual reduction in earnings quality (loss of independence in fact) and the third relates to investor perceptions of lower earnings quality (loss of independence in appearance).

We find that NAS are associated with better quality financial reporting - lower earnings management and higher earnings informativeness. In particular, we find (i) a significant negative association between NAS and the likelihood of reporting a small earnings surprise; (ii) a significant negative association of ISFEE with both absolute discretionary accruals and the likelihood of reporting a small earnings surprise; and (iii) a positive relationship between both NAS and ISFEE and earnings informativeness. Collectively, these results are consistent with the reputation and knowledge spillover hypotheses and are contrary to the economic dependence view (whether in fact or in appearance). Further, even as the use of auditors in IS consulting was more widespread in 1978-80 than in recent years, ISFEE is associated with higher quality earnings supporting the knowledge spillover argument. However, we cannot rule out the possibility that firms that want good financial reporting also buy IS services from their auditor.

One advantage of the 1978-80 setting is that it provides a unique opportunity to exploit the repeal of disclosure requirements to re-examine auditor NAS fee dependence. We do this in

\footnotetext{
${ }^{3}$ When "non-audit fees become large relative to audit fees, auditor independence may be at risk." SEC (2000). Further Kinney et al., (2004) conjecture that "regulators seem not to be concerned that audit fees might be too high or that the audit fee itself might establish economic dependence for the auditor," citing the SEC Chief Accountant Lynn Turner's statements on the effect of high audit fees itself.
} 
two ways. First, we assess stock price reaction around events related to the repeal of ASR 250. If the repeal of NAS disclosure is trivial, we expect no stock price reaction around these events. However, if investors perceived that the disclosure of NAS fee prevents economic dependence, then we expect a negative stock price reactions around these events. Instead, we document a small positive reaction around the events related to the repeal of ASR 250 suggesting that the economic dependence view is not supported.

Second, we examine if NAS fee disclosure disciplined firms to provide higher quality audits by testing if firms lowered earnings quality after the fee disclosure stopped compared to before. Audit firms continued to offer NAS after the disclosure stopped. If the fee disclosure prevented earnings management, we expect to observe lower earnings quality after the disclosure repeal especially for firms that had earlier reported higher NAS fees. We compare earnings quality in FY 1982-84 to earnings quality in the earlier ASR 250 time period. We find that firms that report higher levels of IS fees before the repeal actually have lower earnings management after the repeal. Our results provide no evidence that earnings quality is lower, after the repeal than before, on average or for the sample of firms that reported higher NAS fee dependence.

Our study contributes to research on auditor fee dependence by providing NAS in two ways. First, our paper is a "time dated" or "early history" analysis under a substantially different auditing and business environment compared to the turn of the century when most of the data underlying current work are drawn from. We apply empirical methods for measuring accounting quality (such as absolute abnormal accruals, propensity to report small positive earnings surprises, associations between returns and earnings) that developed later in the literature on data from 1978-1980. Even with the benefit of such hindsight, we do not find evidence that NAS compromise auditor independence in fact or in appearance as measured by resulting accounting 
quality. This inference is consistent with studies that use the 2000 NAS data and enables us to present a historical perspective on the regulatory ban on NAS enacted recently. ${ }^{4}$

Second, our paper is unique among available studies of NAS and economic dependence in investigating the implications of a repeal of disclosures of non-audit fees. The rescinding of ASR 250 provides a unique opportunity to examine market reaction to the repeal of disclosure requirements and earnings quality when fee information was no longer disclosed. These tests are not feasible using data from the recent time period because no restrictions have been withdrawn since the 1980s.

The rest of the paper is organized as follows. Section 2 discusses the institutional background, unique features of NAS data from the earlier period, and outlines the hypotheses. Section 3 discusses the data and the primary earnings quality results. Section 4 presents analyses using the repeal of ASR 250. Section 5 presents additional analyses, and Section 6 concludes.

\subsection{Institutional Background, Prior Research and Hypotheses}

\subsection{History of auditor provided NAS and related concerns}

Zeff (2003) documents that as early as 1910s, accounting firms provided consulting services such as the installation of factory cost systems, studies of organizational efficiency, services related to investments in other businesses, and other services along with audits. Following the Second World War, these included information based services that grew by the mid 1950s to include operations research and electronic data processing. The growth in computing technology provided increasing opportunities for extending such services. For Arthur Andersen, such non audit services accounted for about a fourth of total business by 1969 .

Concerns on compromised audit quality as a result of NAS grew alongside the growth in NAS business. In its 1957 annual report, the SEC voiced early concerns about the breadth of

\footnotetext{
${ }^{4}$ Using 2000-2001 data, the only evidence of a negative relation between NAS and earnings quality is shown by Frankel et al. (2002) and only for a few of several tests. Subsequent research has clarified the limited nature of the Frankel et al. (2002) findings (Defond et al., 2002; Chung and Kallapur, 2003; Ashbaugh et al., 2003). Also, Kinney et al. (2004) find a positive relation between tax consulting and earnings quality.
} 
services offered by auditors and in 1959 the SEC Chief Accountant expressed concern that auditors would lose their objectivity if they provided management advisory services (POB, 2000). Business scandals in the late 1960s led to charges that auditor independence was compromised due to consulting services (Briloff, 1972). In an academic study, Mautz and Sharaf (1961) concluded that management and tax services cloud the appearance of independence. The 1969 AICPA report on auditor independence (AICPA, 1969) found no evidence that NAS impairs independence in fact but that some users may perceive an appearance of lack of independence. Consulting increasingly became a concern for regulators in the 1970s as is discussed next.

\subsection{Developments leading to ASR 250}

In this section, we describe the institutional developments leading to the passage of ASR 250 in 1978. In particular, four events were relevant: (i) accounting scandals in the early 1970s; (ii) extensive price competition; (iii) regulatory concerns over NAS; and (iv) early attempts to split auditing from consulting as a response to ASR 250 and subsequently issued ASR 264.

\subsubsection{Scandals raise concerns about auditor independence}

Zeff (2003) reports that the collapse of Equity Funding in 1973, coming soon after the Stirling Homex bankruptcy a year earlier jolted the auditing industry (Report of the Special Committee on Equity Funding 1975; Seidler, Andrews and Epstein1977). These scandals resulted in two Congressional inquiries, led by Rep. John. E. Moss and Senator Lee Metcalf, that questioned the independence of the auditors from their clients. For instance, in 1977, the Senate Subcommittee on Reports, Accounting and Management (The Metcalf subcommittee) recommended "that the independent auditor of a publicly owned corporation perform only services directly related to accounting. Non-accounting management services such as executive recruitment, marketing analysis, plant layout, product analysis and actuarial services be discontinued.” In response to the increased attention, the AICPA increased self-regulation, forming an SEC practice section (SECPS), required peer reviews of auditors, and set up the Public Oversight Board (POB) (in many respects similar to PCAOB established after SOX) to 
oversee the SECPS and the peer reviews. The AICPA issued the Cohen Commission report in 1978 which recommended that the board of directors or the audit committee of the client be informed of all services provided by the auditor (however prior approval was not required). The SECPS required this disclosure as a membership requirement.

\subsubsection{Extensive price competition}

Kinney (2005) reports that, in 1970s, the Department of Justice and the Federal Trade Commission (FTC) were trying to increase competition in all professions by getting professional organizations to eliminate from their codes of professional behavior elements that were considered as violating federal anti-trust laws. Such pressure led the AICPA to repeal the Code of Professional Conduct ban on competitive bidding for and uninvited solicitation of new audit clients and restrictions on practices such as contingent fees, advertising, and commissions. ${ }^{5}$ As a result, price competition increased as audit firms openly competed for audits and NAS. ${ }^{6}$

Bowman $(1985,705,713)$ documents tenders of between 25 and 50 percent under the previous year's audit fee charged by a company in the early 1980s. Zeff (2003) reports that while earlier clients prized audit quality, they now began to view the audit as a commodity. Maher et al., (1992) document a steep decline in audit fees between 1977 and 1981 which they attribute to the increased competition. Such pricing pressure and the desire to retain their audit clients may lead audit partners to compromise audit quality. If these concerns about deteriorating audit quality are valid, we expect to observe a negative association between financial reporting quality and NAS.

\subsubsection{Non audit services under scrutiny and passage of ASR 250 and 264}

The SEC blamed provision of management advisory services for the perceived decline in auditor independence in the late 1970s (SEC, 1978). Consequently, the SEC issued ASR No. 250, in June 1978, requiring companies to disclose non-audit services provided by its auditor in

${ }^{5}$ According to Zeff (2003), in 1922, the American Institute of Accountants (precursor of the AICPA) banned promotion by accounting firms and since then marketing campaigns for new clients did not exist.

${ }^{6}$ As an example of the competitive pressure faced, the Association of Data Processing Service Organizations, whose members included IBM and Honeywell, contended that the accounting firms special monopoly status to conduct audits gave them an unfair advantage in the consulting business (Hayes 1979). 
proxy statements filed after September 30, 1978. These disclosures consist of total non-audit services as a percentage of total audit fees, the specific nature of non-audit services provided, and for those non-audit services amounting to three percent or more of the total audit fee, their percentages of fees to total audit fees. In addition, disclosure of whether the board of directors or its audit committee approved the services was also required. Note, in particular, that ASR 250 does not mandate the disclosure of total dollar fees for audit services or NAS. The SEC followed up with ASR 264 in 1979 cautioning that "the impact of auditor independence of potential MAS engagements should be of direct concern to the issuer and especially its independent audit committee” (AICPA 1997). ASR 264 also provided guidelines that auditors should use in determining if their independence is compromised and was intended to sensitize auditors and their clients to the potential effects on auditor independence of providing NAS.

\subsubsection{Split between audit and consulting}

Zeff (2003) reports that reacting to Release Nos. 250 and 264, Harvey E. Kapnick, the chairman and chief executive of Arthur Andersen, proposed to his partners in 1979 that the firm be split into two: auditing and consulting. He reported on his private discussions with SEC Chairman Williams, who, he said, would soon require all of the big firms to make such a split. The heated controversy generated by his proposal led him to take premature retirement from the firm several weeks later. In August 1981, under a new Chairman, the SEC announced that it was rescinding ASR 264 and ASR 250 effective February 1982 reflecting according to Zeff (2003, page 204) "the new federal policy of deregulation under President Ronald Reagan.”

Harvey Kapnick’s reaction to ASR 250 and ASR 264 also highlights that in contrast to the specialization and division of labor between the audit and consulting practices in recent times, these functions were more closely integrated in the earlier time period. For example, the day-today governance of Arthur Andersen (the firm with the largest NAS practice) was in the hands of the audit partner in-charge of the local offices. In a typical accounting firm, audit partners controlled all budgets (including that of the NAS), salaries, promotions, etc (Stevens 1991). The 
close relationship between audit and consulting units implies that (i) the potential to accommodate clients due to NAS fees is greater; and (ii) any spillover gains due to synergies and knowledge transfers between the two units are also more likely. Thus, the 1978-80 setting allows for strong tests of the competing explanations of costs and benefits of allowing auditors to provide NAS - if the beneficial spillover effect (fee dependence) dominates, we will be less (more) likely to find an adverse relation between NAS and financial reporting quality.

\subsection{Benefits of using ASR 250 data}

We believe the 1978-80 time period provides a good setting for examining auditor independence related issues on account of (i) extensive price competition discussed in section 2.2.2; (ii) the focus on NAS affecting auditor independence discussed in 2.2.3; and (iii) the integrated nature of auditing and NAS businesses discussed in section 2.2.4. Moreover, information systems (IS) consulting was the biggest component of NAS during 1978-80 (25\% in our sample) relative to late 1990s (see Kinney et al. 2004) allowing us to conduct tests of the knowledge spillover hypothesis. The SEC considers provision of IS by auditors as particularly worrisome and prohibited auditors from offering most types of information systems services (SEC 2000). However, there are costs associated with using ASR 250 data for our tests.

\subsection{Costs of using ASR 250 data}

There was considerable Congressional concern regarding the functioning of the accounting industry in the aftermath of the scandals in the mid-70's, some of which were mentioned in section 2.2.1 that resulted in the passage of the Foreign Corrupt Practices Act of 1977. This concern could have affected auditor behavior in the 1978-80 period such that we may find no association between NAS and financial reporting quality.

While the consulting business was a fast growing area of the audit firms overall business, it had not reached the scale of the late 1990's. As discussed later, our descriptive statistics show that NAS accounted for about $17.4 \%$ of total fees on average for our sample firms. Comparable numbers for the 2001 sample are around 50\% (see Table 2 Frankel et al., 2002). The smaller 
contribution of NAS to total fees and likely smaller dollar values of NAS fees in the 1978-80 time period may potentially weaken support for the economic dependence hypothesis.

While data availability during 1978-80 constrains us to conduct tests using the NAS/Total fee ratio, this measure is consistent the SEC's view that the fee ratio is the relevant measure of the auditor's economic dependence on the client. It is therefore a valid proxy for evaluating the SEC's concerns regarding auditor independence. Note that firms did not disclose the actual dollar value of the fee and hence we cannot conduct tests using the absolute fee amount. Thus, we cannot investigate whether the level rather than the ratio of fees is the appropriate measure of the auditor-client economic bond as suggested by Kinney and Libby (2002) and Francis (2006).

\subsection{Theory of NAS and Auditor Independence}

The Economic Dependence hypothesis, underlying the SEC's concerns of impaired independence, predicts a negative association between NAS and earnings quality. In an attestation role, the auditor has greater power vis-à-vis the client since withholding the attestation can have adverse consequences for the client firm. It is costly for the client to replace the auditor when there is a dispute about earnings quality issues. However, the auditors' desire to provide NAS provides the client with leverage over the auditor since withholding NAS business from the auditor penalizes the auditor without corresponding penalties for the client (changing auditors is costly for firms since it raises earnings quality concerns; withholding NAS from auditors has no similar costs since such services are available from alternate providers). The clients' power vis-àvis the auditor thus increases when the auditor provides consulting services. Therefore, auditors are more likely to accommodate client preferences in the presence of NAS fees and this lack of independence will result in lower earnings quality.

Two alternative hypotheses predict a positive association between NAS and earnings quality. First, Simunic (1984) articulates the knowledge spillover hypothesis arguing that NAS improves audit effectiveness as a better understanding of the client's business due to consulting services improves audit quality. Simunic also finds that greater competition among audit firms 
prevents the auditor from appropriating rents from such efficiencies. The high level of competition in our time period would fit with this scenario. Second, Benston (1975) and Antle (1984) argue (following Klein and Leffler, 1981) that reputation concerns among auditors create incentives for independence. Provision of NAS allows auditors to invest more in reputation capital, which the auditor is unlikely to jeopardize to accommodate any one client (Arrunada, 1999; Dopuch, King and Swartz, 2003). If providing NAS services is correlated with auditor reputation (for instance, high quality clients hire reputed auditors for expert advice), we would expect a positive association between NAS and earnings quality. Finally, concerns about litigation provide another incentive for auditor independence. Since plaintiffs are likely to argue that NAS compromises audit quality, concerns of greater litigation costs provides an incentive to auditors to improve audit quality and we can expect a positive or null association between NAS and earnings quality. Hence, it is not obvious how NAS and financial reporting quality are necessarily related in the data.

\subsection{Prior research}

Prior studies that use ASR 250 data generally provide descriptive evidence and limited tests of the association between NAS and proxies for auditor independence (e.g., Beck et al. 1988a,1988b, DeBerg et al. 1991, Glezan and Millar 1985; Scheiner 1984; Scheiner and Kieger 1982, Parkash and Venable 1993). These studies do not assess the association between NAS and financial reporting outcomes, which is the focus of our paper.

Recent research has used the post-1999 fee disclosure to examine the relationship between NAS fees and lower reporting quality. Frankel et al., (2002) provide the only evidence showing that the NAS fees relative to audit fees ratio is associated with greater earnings management as measured by discretionary accruals and a greater propensity to meet earnings benchmarks. Subsequent research clarifies the limited nature of the Frankel et al. (2002) finding. For instance, Reynolds et al., (2004) find that the Frankel et al. (2002) result is only present among small to medium sized high growth firms in specific industry segments and Larcker and 
Richardson (2004) isolate the NAS ratio and accrual relationship only in a small subset of smaller, management controlled companies. Chung and Kallapur (2003) and Ashbaugh et al., (2003) find that the Frankel et al., (2002) results are not robust to methodological weaknesses they identify. The no relation evidence is supported by Defond et al., (2002) using going concern opinions and by Ruddock et al (2006) using a sample of Australian firms and accounting conservatism. Further, Antle et al (2006), Ashbaugh et al, (2003), Chung and Kallapur (2003), Francis and Ke (2003), and Reynolds et al (2004) find no consistent evidence when the value of NAS or total fees is the independent variable instead of the ratio measure.

Prior papers find no fee difference between restatement companies and a control group, for unexpected NAS fees and ratios (Whisenant, Sankaraguruswamy, and Raghunandan 2003) and NAS fee ratio or frequency of NAS fees over \$1 million (Agrawal and Chadha, 2003). Kinney et al., (2004) use a proprietary dataset of audit and non audit fees from 1995 to 2000 thus prior to the events immediately preceding passage of SOX in 2002. Kinney et al. is most similar to the present paper in that (i) it analyzes NAS fees by service type and relates it to financial reporting quality (proxied by accounting restatements); (ii) some types of fees (tax consulting fees) are associated with higher earnings quality (and "other" NAS is associated with lower quality), and (iii) it is also based on 20th century data and not fee data from 2001. Overall, there is very limited evidence of a positive relationship between different measures NAS fee dependence and weaker financial reporting quality, evidence characterized by Kinney et al (2004) as scattered and modest.

\subsection{Data and Results}

\subsection{Sample and data collection}

Our sample consists of all firms that comprised the S\&P 500 in December $1978 .{ }^{7}$ Under ASR 250, companies were required to report their NAS fees as a percentage of the audit fees

\footnotetext{
${ }^{7}$ Our sample firms comprise approximately $67 \%$ of the market capitalization of the entire CRSP universe for the time period of the study.
} 
starting September 30, 1978. These disclosures were discontinued in 1982 when the SEC rescinded ASR 250. We hand collect data on NAS ratio from annual proxy statements for the fiscal years 1978-80 for 1,281 firm years for our sample companies.

\subsection{Descriptive statistics}

Panel A of Table 1 presents a summary of the magnitudes of non-audit services for all companies in the sample and Panel B provides firm-level descriptive statistics. The mean (median) non-audit fees (NAS) account for 17.5\% (14.5\%) of total fees in the 1978-1980 period. ${ }^{8}$ The economic magnitude of NAS during our sample period is smaller than the comparable numbers in the 2001 data where NAS accounts for $49 \%$ of total fees at the mean level (see Table 2 of Frankel et al. 2002). The service most frequently provided during our sample period is assistance with tax related issues - 79\% of sample firms report tax fees, a number comparable to about $77 \%$ for non-restating companies in Kinney et al. (2004). In terms of economic importance, information systems related fees dominate - an average of $14.6 \%$ of total fees for firms that disclose this fee separately (compared to $2 \%$ in recent data per Frankel et al., 2002) and $25 \%$ of the firms in the sample report ISFEES separately (compared to 5\% reported in Kinney et al., 2004). The median percentages reveal a slightly different picture in that the highest proportion of total fees paid relates to tax consulting at 9.7\%. These statistics in comparison to recent data shows while that NAS services increased considerably since 1980, IS services were offered less by audit firms whereas audit firms retained their role in providing tax services at similar levels (but at greater dollar magnitudes). Untabulated results show that Arthur Andersen was the dominant provider of NAS in general and information systems, tax, and M\&A services in particular for our sample. Ernst and Whinney leads in H\&R services whereas Price Waterhouse leads in legal services.

\subsection{Empirical measures of fee dependence}

\footnotetext{
${ }^{8}$ We convert the NAS/Audit fee ratio to NAS/Total fee ratio to maintain comparability with post 2000 data used in other papers.
} 
We use two measures of fee dependence. The first measure is the NAS ratio calculated as ratio of total non-audit fees to total fees paid to the auditor and the second is ISFEE which is the ratio of fees paid for information services to total fees paid to auditor. We consider ISFEE separately for multiple reasons. First, ISFEE is the largest component of NAS (See Table 1) and by virtue of its size merits separate examination. ${ }^{9}$ Second, IS fees have attracted regulatory criticism and auditors are currently prohibited from offering many types of information systems services to audit clients (SEC 2000) due to the concern that corporate information systems are part of the firm’s financial reporting system that is being audited. In providing IS services the audit firm would need to audit its' own work creating potential for abuse. On the other hand, auditors argue that implementing information systems allows them better insight into the client thus improving audit quality. This phenomenon played a bigger role in our setting since the use of auditors for IS consulting appears to have been more widespread in the late 70's than in the late 90's. ${ }^{10}$ Further, the consulting divisions were more closely integrated with the audit function in the 1970's as the audit partners were in effective control of non-audit services as well (Stevens 1991). This suggests that economic dependence or synergy related outcomes are more likely to manifest themselves in the relationship with clients. Therefore, IS consulting provides a setting where empirical detection of any underlying relationship is more likely.

\subsection{Empirical measures of earnings quality}

We adopt three empirical measures of earnings quality (and therefore audit quality): (i) absolute discretionary accruals; (ii) the probability of meeting or beating earnings benchmark; and (iii) the stock market's perception of earnings quality measured as the earnings response

\footnotetext{
${ }^{9}$ We also examine tax fees separately (discussed in the additional analysis section) since it is the type of service availed by the largest number of companies. However, tax services have not been considered as affecting independence by the SEC and have never been the subject of much controversy.

${ }^{10}$ As mentioned earlier, around 25 percent of our sample firms obtain IS consulting from their auditors. In contrast Kinney et al. (2004) find that only 5\% of companies availed information systems consulting from their auditors in the late 1990's.
} 
coefficient. ${ }^{11}$ We acknowledge that each of these empirical measures of earnings quality and the market's perception thereof has limitations. For example, as Kinney and Libby (2002) point out, the benchmark measure categorizes all firms that meet or beat the benchmark as firms with poor quality earnings, regardless of whether the goal was achieved via earnings management, expectations management, reduction in uncertainty or improvements in operations. Conversely, a firm that is consistently well below the benchmarks will be categorized as one with high quality earnings although the firm might have manipulated earnings by large amounts. Discretionary accruals might just identify firms that engage in transactions that involve complex judgments and estimates. Our hope is that different proxies for earnings quality will provide convergent results and thus reduce the possibility that the inferences are driven by method-specific bias.

\subsection{Multivariate analysis}

\subsubsection{Discretionary accruals}

Similar to prior research, we estimate discretionary accruals using the cross-sectional version of the modified Jones model (Jones 1991) to measure earnings management as below:

$$
A C C_{i, t}=\delta_{0} 1 / T A_{i, t-1}+\delta_{1}\left(\Delta S A L E S_{t}-\Delta A R_{t}\right) / T A_{i, t-1}+\delta_{2} P P E_{i, t} / T A_{i, t-1}+D A C C_{i, t}
$$

where ACC = total accruals deflated by $\mathrm{TA}_{\mathrm{it}-1}$ where accruals are computed as changes in working capital ( $\Delta$ Current Assets - $\Delta$ Current Liabilities - $\Delta$ Cash and Equivalents $+\Delta$ Short Term Debt - Depreciation and Amortization Expense). ${ }^{12}$ TA is total assets at the beginning of the year; SALES refers to sales; AR is the accounts receivables; PPE is property, plant and equipment; and DACC is the discretionary accruals computed as the residual from fitting the model in (1).

We rely on the absolute value of DACC or $|\mathrm{DACC}|$ as our measure of earnings management because both income-increasing and income-decreasing accruals (e.g., cookie jar

\footnotetext{
${ }^{11}$ We considered but decided against conducting two other tests. First, Defond et al. (2002), investigate associations between the incidence of qualified opinion in distressed firms and NAS. However, almost none of our S\&P500 firms is distressed. Second, Kinney et al. (2004), examine the association between earnings restatements and NAS. Obtaining data on earnings restatements for our sample period is difficult. ${ }^{12}$ We cannot follow the Hribar and Collins (2002) recommendation of defining accruals as the difference between earnings and cash from operations because CFO disclosure was mandated after our sample period.
} 
reserves) potentially constitute earnings management. ${ }^{13}$ Consistent with Chung and Kallapur (2003) we estimate the following model to assess if NAS fees are associated with |DACC|:

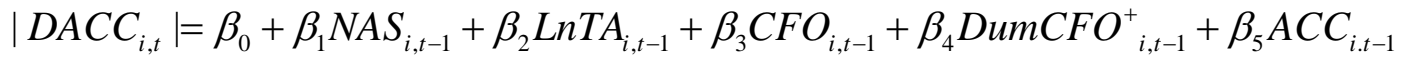
$+\beta_{6}$ DumACC $_{i, t-1}^{+}+\beta_{7}$ ROA $_{i, t-1}+\beta_{8}$ DumROA $_{i, t-1}^{+}+\beta_{9}$ DumACQ $_{i, t}+\beta_{10}$ DumISSUE $_{i, t}$ $+\beta_{11} M B_{i, t-1}+\beta_{12} L_{E V_{i, t-1}}+\beta_{13}$ CFOVOL $_{i, t}+\beta_{14}$ DumLitigation $_{i, t}$ $+\gamma$ IndustryDummies $_{i, t}+\delta$ YearDummies $_{t}+\varepsilon_{t}$

where LnTA = log of total assets; DumCFO ${ }^{+}=$dummy variable set equal to 1 if CFO (computed as income before extraordinary items less total accruals) is positive and zero otherwise. DumACC $^{+}$and DumROA ${ }^{+}$are defined similarly to DumCFO ${ }^{+}$. DumACQ is a dummy variable set to 1 if the firm acquired another firm during the year, and 0 otherwise. DumISSUE is dummy variable set to 1 if the number of shares outstanding, adjusted for splits and dividends, increases by $10 \%$ over the previous year; and 0 otherwise. DumLitigation is a dummy set to 1 if the firm is in a highly litigious industry, as identified from the auditor litigation database provided by Palmrose (1999). The following industries are deemed litigious: mining (SIC2 code 13), manufacturing (SIC2 code 20, 33 to 37), retailing (SIC2 code 52 to 59) and financial services (SIC2 code 61 to 66). Since the statement of cash flows was not available during our sample period we use balance sheet information to compute accruals.

Following the method suggested in Hermalin and Weisbach (2003) to address endogeneity concerns, we lag the NAS variable by a year relative to discretionary accruals (|DACC|) and do not model NAS and |DACC| as a system of simultaneous equations. ${ }^{14}$ Note that CFO and ROA are included to account for the correlation between accruals and these variables (Dechow, Sloan and Sweeney 1995). Lagged accruals are included to account for potential reversals in accruals. The dummies to identify positive CFO, ACC and ROA allow the coefficients of $|\mathrm{DACC}|$ to differ depending on the sign of performance. The DumACQ variable is

\footnotetext{
${ }^{13}$ Sensitivity analyses with signed discretionary accruals shows there is no change in our inferences.

${ }^{14}$ As we use lagged NAS in all our subsequent tests, we remove observations that reflect an auditor change.
} 
included to address Hribar and Collins’ (2002) concerns that accruals calculated using the balance-sheet method (as here) are contaminated by how acquisitions are accounted for. The DumISSUE variable addresses the concern that firms might manipulate discretionary accruals (Teoh et al, 1998) although this view is controversial (Ball and Shivakumar 2008). Growing firms are expected to have greater accruals, hence the inclusion of MB. Firms with greater leverage (LEV) have incentives to manage accruals to affect creditors’ perceptions of earnings performance. To account for potential model misspecification arising from tests of unsigned discretionary accruals (Hribar and Nichols 2007), we include the control variable cash flow volatility (CFOVOL), computed as the standard deviation of operating cash flow for the 16 quarters ending with the year of observation. To control for litigation risk, we include DumLitigation (Matsumoto 2000). Industry and time dummies are included to pick up any systematic patterns in |DACC| across industries and years.

If the economic dependence hypothesis were supported, we expect a positive $\beta_{1}$ coefficient on NAS. A negative coefficient would be consistent with knowledge spillovers or the auditor's reputation concerns or litigation risk mitigating the effect of economic dependence. Table 2 reports the results of estimating equation (2). Column 1 presents the results with NAS and column 2 with ISFEE. Column 1 indicates no association between absolute discretionary accruals and NAS. Column (2) shows a negative and significant coefficient (t-statistic -1.81) on ISFEE and provides support for the synergy and knowledge spillover explanation. There is no support for the economic dependence hypothesis with either NAS or ISFEE unlike that in Frankel et al., (2002) and consistent with Ashbaugh et al., (2003) and Reynolds et al., (2004) who however find a null relationship as discussed earlier. To our knowledge prior papers have not examined ISFEEs and discretionary accruals. The coefficients on the control variables are generally consistent with prior work (Chung and Kallapur 2003; Hribar and Nichols 2007). ${ }^{15}$

\footnotetext{
${ }^{15}$ All t-stats are based on standard errors that are clustered by firm. Throughout our discussion of the results, we use a level of $10 \%$ or lower two sided significance to identify statistically significant results.
} 


\subsubsection{Meeting-beating earnings benchmarks}

Prior research documents that managers care about meeting or beating earnings benchmarks and use accounting-based or real earnings management to meet or beat these benchmarks (e.g., Burgstahler and Dichev 1997; Degeorge et al. 1999; Graham, Harvey, and Rajgopal 2005; Mergenthaler, Rajgopal and Srinivasan, 2011). If NAS fee dependence causes auditors to allow such earnings management, we would observe a positive association between the meeting/beating behavior and NAS. Given that the data are from 1978-80, analyst induced pressure on managers to meet forecasts is perhaps less of a concern in that time period (Brown and Caylor 2005). Hence, we only investigate whether managers in that time period have incentives to report annual earnings momentum. We examine annual as opposed to quarterly earnings because (i) auditor involvement with quarterly earnings is lesser than for annual earnings; and (ii) managerial obsession with quarterly earnings is often thought to be a phenomenon that intensified in the 1990s (Graham et al. 2005). We employ the following logit model, where DumSURP is a dummy variable set to 1 if the firm reports a small positive surprise in annual earnings. A small positive surprise occurs when the change in lagged annual net income scaled by total assets at the end of year t- 1 falls within the range of (0.00 to 0.01$)$.

$$
\begin{aligned}
& \text { DumSurp }_{i, t}=\beta_{0}+\beta_{1} \text { NAS }_{i, t-1}+\beta_{2} \text { LnTA }_{i, t-1}+\beta_{3} \text { CFO }_{i, t-1}+\beta_{4} \text { ROA }_{i, t-1}+\beta_{5} \text { DumROA }_{i, t-1}^{+} \\
& +\beta_{6} \text { DumACQ }_{i, t}+\beta_{7} \text { DumISSUE }_{i, t}+\beta_{8} M_{i, t-1}+\beta_{9} \text { DumLitigation }_{i, t} \\
& +\gamma \text { IndustryDummies }_{i, t}+\text { SYearDummies }_{t}+\varepsilon_{t}
\end{aligned}
$$

Consistent with the approach in section 3.5.1 to address endogeneity concerns, we lag NAS by a year. LnTA is included to address the possibility that large and therefore more visible firms are more interested in meeting and beating earnings benchmarks. Brown (2001) finds that loss firms are more likely to report positive earnings surprises. Hence, we include ROA and DumROA $^{+}$in the model. Of course, ROA and CFO account for the possibility that better performing firms are more likely to meet or beat earnings benchmarks. Firms that acquire other firms (DumACQ) or engage in financing activities (DumISSUE) are more likely to positively 
affect investors' perceptions by meeting or beating benchmarks. We include a proxy for growth (MB) and the litigation environment (DumLitigation) in model (3) because Matsumoto (2002) argues that firms with high growth prospects and high litigation risk are more likely to meet or beat earnings benchmarks.

If the economic dependence hypothesis were supported, we expect a positive $\beta_{1}$ coefficient on NAS. Otherwise, a negative coefficient on NAS, as before, could reflect the effect of knowledge spillovers, concerns about auditor reputation or litigation risk on manager's proclivity to meet or beat earnings benchmarks. Results related to the estimation of equation (3) are reported in Table 3. As before, columns 1 and 2 present the results with NAS and ISFEE. The results reveal a statistically significant negative association between the tendency to meet or beat annual earnings benchmarks and NAS and ISFEE $\left(\chi^{2}\right.$ - statistic on NAS in column 1 is 3.59 and on ISFEE in column 2 is 5.14). This suggests support for the knowledge spillover and reputation/litigation risk explanations implying that NAS improves auditors ability to prevent earnings management. Consistent with prior research, firms’ proclivity to meet or beat annual earnings benchmarks is positively associated with firm size $\left(\chi^{2}\right.$ - statistic on LnTA $=35.5$ in column 1) and profitability ( $\chi^{2}$-statistic on $\mathrm{DUMROA}^{+}=13.25$ and $\chi^{2}$-statistic on ROA is 12.2$)$.

\subsubsection{Earnings response coefficient}

Regulatory concern about NAS arises not only due to independence "in fact” but also about independence "in appearance” i.e., the SEC worries that investor confidence in financial reporting is lowered by the appearance of fee dependence even if independence is actually not compromised (The AICPA Code of Professional Conduct Article IV, Previts 1985, SEC 2000). If high NAS reflects greater auditor fee dependence on the client and investors perceive this as lowering earnings quality, the informativeness of earnings as an explanatory variable for stock returns will decrease in NAS. This is because investors reckon that managers in high NAS firms exploit their latitude in financial reporting to obfuscate real economic performance. If instead, investors perceive high NAS to reflect knowledge spillovers that are beneficial to the firm, we 
would find a positive association between NAS and the informativeness of earnings for stock returns.

Similar to Warfield, Wild and Wild (1995) we rely on the following empirical specification to investigate the relation between NAS and the informativeness of earnings: ${ }^{16}$

$$
\begin{aligned}
& \left.\operatorname{RET}_{i, t}=\beta_{0}+\beta_{1} \text { Earnings }_{i, t}+\beta_{2} \text { Earnings }_{i, t} * N A S_{i, t-1}\right)+\beta_{3}\left(\text { Earnings }_{i, t} * \text { LnTA }_{i, t-1}\right) \\
& +\beta_{4}\left(\text { Earnings }_{i, t} * \text { Risk }_{i, t}\right)+\beta_{5}\left(\text { Earnings }_{i, t} * \operatorname{LEV}_{i, t-1}\right)+\beta_{6}\left(\text { Earnings }_{i, t} * M B_{i, t-1}\right) \\
& +\beta_{7}\left(\text { Earnings }_{i, t} * \operatorname{VAR}_{i, t}\right)+\beta_{8}\left(\text { Earnings }_{i, t} * \operatorname{PERS}_{i, t}\right)+\gamma \text { IndustryDummies }_{i, t} \\
& +\delta \text { YearDummies }_{t}+\varepsilon_{t}
\end{aligned}
$$

where RET = market-adjusted stock returns beginning from fiscal month 4 and ending in following year fiscal month 3. RISK is a firm's systematic risk computed using monthly returns for five years ending with the year related to the NAS disclosure, VAR is variability of earnings for the sixteen quarters ending with the year related to the NAS disclosure and PERS is the persistence of earnings as measured by the first-order autocorrelation in earnings for sixteen quarters ending with the year related to the NAS disclosure. All other variables are as previously defined. Similar to the earnings management tests, we lag NAS data by a year to allow the stock market to evaluate NAS disclosures available from the previous year's proxy statements.

If the economic dependence hypothesis held, we expect a negative $\beta_{2}$. If the alternate hypothesis of knowledge spillovers held, we expect a positive or a zero $\beta_{2}$. The results of estimating equation (4) are presented in Table 4. Column 1 estimates with total non-audit fees to total fees ratio as the NAS measure shows a significant positive association between ERC and NAS, as can be seen from the significant t-statistic $(\mathrm{t}$-stat $=1.73)$ on the Earnings*NAS variable. Column 2 estimates are also consistent with this finding - the coefficient on the Earnings*ISFEE is also positive and significant $(\mathrm{t}$-stat $=1.76)$. Consistent with prior research (Warfield, Wild and Wild 1995), the ERC is decreasing in earnings variability (coefficient $\beta_{7}$ is negative and

\footnotetext{
${ }^{16}$ Note that we cannot conduct an event study around the release of proxy statements containing NAS fee data because the filing dates on the microfiche versions of proxy statements were unavailable in most cases. We also investigate the short-window abnormal returns surrounding the earnings announcement dates and found no association between earnings informativeness and the three measures of auditor independence.
} 
significant). The results support the view that providing NAS and IS enables knowledge transfers that can improve the quality of audits and hence informativeness of earnings.

To summarize, NAS is not associated with discretionary accruals, lowers earnings management associated with a firm's proclivity to meet or beat annual earnings targets and is positively associated with earnings informativeness. The results using the information technology component of total non-audit fees - ISFEE, are also consistent with these findings. ISFEE is negatively associated with earnings management measured both with discretionary accruals and firms' proclivity to meet or beat earnings targets and is positively related with earnings informativeness. ${ }^{17}$

Overall, these results support the view that NAS are associated with better financial reporting. None of the results in our paper are consistent with the economic dependence hypothesis, underlying the SEC’s concerns about impaired independence. Findings using more recent data show that NAS fee measures are not associated with lower earnings quality - the results in this paper go one step further by suggesting that NAS can in fact have a positive relationship with earnings quality. However, an important caveat deserves mention. Our tests document associations between financial reporting quality and NAS or ISFEE and not necessarily causal relations. That is, we cannot rule out the possibility that firms that want good financial reporting also hire their auditors to perform NAS (or IS services).

\subsection{Economic consequences of repeal of NAS disclosures}

The disclosure of NAS fee information can act as a deterrent to auditor fee dependence. If the market monitors higher fee dependence clients more closely, such firms are less likely to bias their accounting numbers. This monitoring role has served as the motivation for the SEC to require this disclosure and could be the reason for the null results obtained using post-1999 data

\footnotetext{
${ }^{17}$ Kinney et al. (2004) find no significant relationship between IS consulting and restatements but that result can be driven the small number of companies that avail IS services from auditors in their sample.
} 
and our positive association results. In other words, behavior observed under disclosure is not representative of behavior when there is no fee information available. One advantage of our setting is that it provides us with the unique opportunity to exploit the withdrawal of the disclosure to construct tests of auditor fee dependence. We do this in two ways. First, we assess the stock price reaction of our sample firms around the events related to the repeal of ASR 250 . Second, we examine our earnings quality constructs after the fee information is withdrawn compared to when fees were disclosed to assess if earnings quality deteriorated in the absence of the disclosure.

\subsection{Market Reaction to Repeal of NAS Disclosure}

The repeal of ASR 250 was sudden, somewhat unexpected, and implemented rather quickly. This feature allows us to study the stock price reactions to the events leading to the repeal of ASR 250. A review of the events leading up to the repeal suggests that three dates are worthy of study. On August 20 1981, the SEC proposed a rescission of ASR 250 (event 1). On September 9, 1981, the SEC Practice Section of the AICPA requires audit firms to report NAS to the AICPA in private communication instead of publicly reporting such data (event 2). Finally, on January 28, 1982, the SEC formally rescinded ASR 250 (event 3). Assuming that the expected probability of the recession of ASR 250 increased on the above dates, we expect to observe no stock price reaction around these dates if the requirement to drop disclosure of NAS fee is valueirrelevant. However, if investors thought that NAS fees disclosure prevents auditor fee dependence, then we ought to observe negative stock market reactions around these events.

Table 5 presents market-model based stock price reactions for a three-day window around these three event dates. The overall stock price reaction for events 1 and 2 is positive and statistically significant. However, there is no significant reaction to event 3 . When we aggregate the stock market reactions for the three event dates, the overall market response is positive and significant but somewhat small (0.8\%). There is some evidence that firms with higher NAS and ISFEE actually experienced more positive reactions relative to firms with smaller NAS and 
ISFEE. Multivariate results reported in panel B, after the introduction of appropriate controls such as size, beta and $\mathrm{M} / \mathrm{B}$, suggest that the univariate association between stock price reactions to the event dates and NAS disappear as the coefficient on NAS is insignificant in column 2. However, we continue to observe a positive coefficient of 0.064 on ISFEE suggesting that prior to the repeal of public disclosure, firms were potentially purchasing sub-optimal levels of IS from audit firms. Equally importantly, we do not observe a negative reaction to the repeal of ASR 250 suggesting that the economic dependence story is, once again, not supported.

\subsection{NAS and Earnings Quality After Repeal of ASR 250}

We examine if earnings quality worsened after the NAS disclosures were withdrawn. To do so, we expand the sample to include data for three years after the disclosure was withdrawn (i.e. fiscal years 1982 - 84) and repeat the earnings quality tests we conducted earlier adding a indicator variable for the post-ASR 250 time period (POST). Further, we test whether the deterioration, if any, is greater for firms that had reported greater NAS ratios during the disclosure period (DumHighNAS, measured as a dummy variable that takes the value 1 if above median of last reported NAS/ has ISFEE). The regression for the discretionary accrual test is similar to equation 2 above.

$$
\begin{aligned}
& \mid \text { DACC }_{i, t} \mid=\beta_{0}+\beta_{1} \text { POST }_{i, t}+\beta_{2} \text { DumHighNAS }_{i, t}+\beta_{3}\left(\text { POST }_{i, t} \text { DumHighNAS }_{i, t}\right)+\beta_{4} \text { DumCFO }_{i, t-1}^{+} \\
& +\beta_{5} \text { LnTA }_{i, t-1}+\beta_{6} \text { CFO }_{i, t-1}+\beta_{7} \text { DumCFO }_{i, t-1}^{+}+\beta_{8} \text { ACC }_{i, t-1}+\beta_{9} \text { DumACC }_{i, t-1}^{+}+\beta_{10} \text { ROA }_{i, t-1} \\
& +\beta_{11} \text { DumROA }_{i, t-1}^{+}+\beta_{12} \text { DumACQ }_{i, t}+\beta_{13} \text { DumISSUE }_{i, t}+\beta_{14} \text { MB }_{i, t-1}+\beta_{15} \text { LEV }_{i, t-1}+\beta_{16} \text { CFOVOL }_{i, t} \\
& +\beta_{17} \text { DumLitigation }_{i, t}+\gamma \text { IndustryDummies }_{i, t}+\text { SYearDummies }_{t}+\varepsilon_{t}
\end{aligned}
$$

Similarly, we also test the propensity to meet earnings targets (equation 3) and earnings response coefficient (equation 4) by introducing POST and DumHighNAs into those estimations.

If we find lower earnings quality in the post ASR 250 time period, especially for the firms that earlier reported higher NAS ratios we would conclude that NAS fees were associated with lower earnings quality but the disclosure likely acted as a check preventing a deterioration in audit quality. However, in the absence of disclosure, audit quality impairment occurs. One 
maintained assumption in these tests is that NAS ratios in the three years subsequent to ASR 250 repeal stayed similar to the levels reported earlier. We believe this is a reasonable assumption since consulting assignments are multi-year in nature and do not change very quickly.

Table 6 panels A, B and C present results of the behavior of discretionary accruals, propensity to meet earnings targets and earnings informativeness tests respectively. Panel A results show no evidence that discretionary accruals increased in the POST ASR 250 time period. Further, there is no evidence that firms with higher NAS ratios in the ASR 250 period have higher levels of discretionary accruals in the post-ASR 250 period than those with lower NAS ratios. Both these results hold for NAS and ISFEE. In fact, firms with higher levels of IS fees report lower discretionary accruals suggesting higher earnings quality, similar to the results in Table 2 . Results in Panel B are similar - we find no support for the fee dependence hypothesis for both measures of fee dependence. The propensity to achieve small earnings surprises decreases for High IS Fee firms in the post ASR 250 period again suggesting improved earnings quality. Panel C results suggest that earnings informativeness improved in the post ASR 250 time period with no difference between the high and low NAS (of ISFEE) groups. These results also go against the fee dependence hypothesis. In sum, the evidence provides no support for the fee dependence view; instead there is some support for higher IS fees leading to improvements in earnings quality in the post ASR 250 time period supporting the knowledge spillover hypothesis.

\subsection{Additional analyses}

\subsection{Unexpected NAS}

Our analysis so far does not separate an expected portion of NAS from an unexpected portion because the expected amount of NAS that clients avail from their auditors is zero. There is no need for a client to obtain consulting services from their auditor in a competitive consulting market and indeed they are zero for many firms. Any NAS from the auditor can be considered as unexpected. Therefore, NAS models do not have as much explanatory power as audit fee models 
Francis (2006). However prior papers (Parkash and Venable 1993, Firth 1997, Frankel et al, 2002, Kinney and Libby 2002, Ruddock et al. 2006) argue that some of the cross-sectional variation in NAS is a predictable function of firm characteristics. To assess whether such predictable variation exists and if it affects our inferences, we employ only the unexpected portion of the NAS ratio as our proxy for auditor fee dependence. Following prior work (e.g., Frankel et al. 2002), we estimate the following model to extract the unexpected portion of NAS: ${ }^{18}$

$$
\begin{aligned}
& \text { NAS }_{i, t}=\beta_{0}+\beta_{1} \text { DumBig }_{i, t}+\beta_{2} \text { ROA }_{i, t}+\beta_{3} \text { DumLOSS }_{i, t}+\beta_{4} \text { RET }_{i, t}+\beta_{5} \text { CFO }_{i, t} \\
& +\beta_{6} \text { LEV }_{i, t}+\beta_{7} \text { INVREC }_{i, t}+\beta_{8} \text { LnMVE }_{i, t-1}+\beta_{9} \text { MB }_{i, t}+\beta_{10} \text { DumSPECIALIST }_{i, t} \\
& +\gamma \text { IndustryDummies }_{i, t}+\text { SYearDummies }_{t}+\text { UXNAS }_{i, t}
\end{aligned}
$$

where NAS = non-audit fees divided by total fees; DumBig8 is a dummy variable set 1 if the firm's auditor is a Big 8 firm and 0 otherwise; ROA = income before extraordinary items deflated by beginning-of-year total asset; DumLOSS = dummy variable set to 1 if the firm reports a loss of net income in the year $\mathrm{t}$ and 0 otherwise; RET = market-adjusted annual stock returns; $\mathrm{CFO}=$ cash from operations divided by the beginning-of-the year total assets; LEV = ratio of total longterm debt to total assets; INVREC = inventory and accounts receivable, deflated by beginningof-year total assets; LnMVE = natural log of the market value of equity; MB = market-to-book ratio; DumSPECIALIST = dummy set to one (zero) if the audit firm has the largest number of clients in the two-digit SIC code; and UXNAS = the unexpected portion of the NAS ratio.

In untabulated analysis, we find that the above model is only modestly successful at explaining cross-sectional variation in NAS with an adjusted r-squared of just 9\%. Consistent with expectations, NAS is higher in firms with larger investment opportunity sets (t-statistic related to MB is 2.05) and when the auditor is an industry specialist (t-statistic related to DUMSpecialist is 3.06). Untabulated results confirm that using UXNAS, instead of NAS, does not alter our reported inferences.

\footnotetext{
${ }^{18}$ Brown, Falaschetti and Orlando (2010) object to estimating UXNAS from contemporaneous data (i.e, most of the independent variables in equation 6 are measured at time t). We estimated a version of eq. (6) with independent variables lagged by a year (t-1) and find results similar to those reported in the paper.
} 


\subsection{Tax fees}

Gleason and Mills (2011) use Internal Revenue Service, financial statement and auditor fee data from 2000 to 2002 and conclude that auditor-provided tax services are associated with more accurate estimates of tax expense, consistent with knowledge spillover and contrary to concerns about independence failure. In untabulated work, we repeat our analyses related to our proxies for financial reporting quality with the ratio of fees for tax services to total fees paid to the auditor. We find no association between the three proxies of earnings quality and the proportion of tax related fees to total fees. Thus, our analysis of tax fees yields results generally consistent with the overall result of no support for the economic dependence hypothesis. However, these results vary from those in Kinney et al, (2004), who find that tax fees are associated with lower propensity to restate earnings i.e., higher accounting quality.

\subsection{Conclusions}

In this paper, we use disclosure of fees paid to auditors for their audit and non-audit services (NAS) during the years 1978-80 for a sample comprised of S\&P 500 firms to investigate whether high NAS fees relative to audit fees is associated with poor quality financial reporting.

We find that greater extent of non-audit services is associated with improvements in earnings quality - lower likelihood of reporting a small earnings surprise and an increase in earnings informativeness. These results provide no support for the economic dependence hypothesis, underlying the SEC's concerns about impaired independence. We repeat our tests using fees related to information systems consulting. Consistent with the knowledge spillover hypothesis, the results suggest that greater IS consulting fees are associated with higher quality financial reporting for all three proxies of earnings quality. The positive relationship of earnings quality with IS fees supports arguments that this area of consulting improves the audit firms knowledge base leading to improved audit quality. Further, events related to the repeal of ASR 250 by the SEC are not associated with a negative share price reaction suggesting that the market 
does not fear an increase in economic dependence from the non-disclosure of NAS. Finally, we find no evidence that earnings quality deteriorated after the SEC repealed ASR 250.

Tests of the association between earnings management proxies and measures of NAS fee dependence are a test of the auditor's independence in fact while the earnings informativeness and the market reaction tests of the ASR 250 repeal are tests of independence in appearance. Evidence from the earnings management tests suggests that NAS and ISFEE appear to improve earnings quality and do not compromise auditor independence in fact for our sample. The positive association between NAS and earnings informativeness and the absence of a negative reaction around the event dates related to the repeal of ASR 250 is consistent with no impact of NAS on independence in appearance either. Our results on the beneficial earnings quality impact of non-audit services raises concerns that political interventional in the audit industry can adversely affect financial reporting quality in firms.

Our conclusions are subject to the specific institutional features of the time period of our setting. The 1978-80 time period provides a setting where the auditors incentives to compromise audit quality were likely to be strong. The audit industry had just been opened to intense competition due to relaxation of ethics rules, the industry had larger number of significant players (but became more concentrated later), NAS services were rapidly growing, IS consulting was prevalent than in the late 90s, and the close relationship between auditing and consulting divisions in audit firms made it easier to lower audit quality for consulting fees. These conditions provide a good setting to test for loss of independence in fact and in appearance. Despite these enabling conditions, we find no evidence of lower earnings quality but instead the opposite. This allows us to conclude that providing NAS does not automatically lead to weaker audit quality. Since, companies disclosed only the ratio of NAS fees to total fees, our evidence does not relate to the size of the fees but does inform on the effect of the relative extent of NAS fees, which is the SEC construct of auditor fee dependence. 
NAS fees were a smaller proportion of total fees to the auditor (17\%) in our setting than in recent times (50\%) and likely smaller in absolute amounts as well. The positive association of NAS with earnings quality we document could be a reflection of the beneficial impact of NAS when present in modest amounts. Therefore one cannot conclude that NAS are always associated with better earnings quality. Information systems consulting was more prevalent in our setting than in recent times and we find earnings quality improvements associated with IS fees. This suggests that the benefits of NAS are dependent on the type of consulting service provided by the auditor. This result is consistent with benefits from another type of NAS - tax consulting documented in Kinney et al. (2004). Governance mechanisms have also changed over time. ASR 250 requirements did require audit committees to consider the potential loss of auditor independence from NAS similar to requirements in more recent time periods. However, audit committees were of much more recent origin in the late 1970s and were more likely to have inside directors - hence not as independent as in recent times. Despite this, we do not document an adverse association of NAS with earnings quality. Finally, we do not make any causal conclusions as we can only conduct tests of association.

The predominant weight of evidence from papers that use post-1999 NAS fees data is that NAS is not detrimental to earnings quality. However, there are concerns about the generalizability of these findings. First, these are null results and do not document benefits either. Second, Kinney and Libby (2002) note that using a single year of data can produce idiosyncratic results. For instance, Reynolds et al, (2004) state that FY 2000 “was characterized by an infatuation with e-commerce, a merger boom, and IPOs tied to the new economy”. Finally, this was a period of intense scrutiny of audit firms by the SEC which would check any normal impulses to lower audit quality (Antle et al., 2006; Ruddock et al., 2006). Our results provide a triangulation of the post-2000 results with evidence from a very different setting. The lack of earnings quality decline documented from very different institutional settings strengthens the evidence against deterioration of audit quality in the presence of NAS. 
Watts and Zimmerman (1981) argue that "the onus of documenting that the existence of benefits from restrictions (on auditors providing NAS) exceeds the costs, is placed on proponents wishing to restrict auditors’ actions.” Our paper provides another piece of evidence to suggest that there is no empirical basis for political intervention via audit practice restrictions by Congress and the SEC. 


\section{References}

Agarwal, A., and S. Chadha. 2005. Corporate Governance and Accounting Scandals. Journal of Law and Economics, 48(2): 371-406.

AICPA Code of Professional Conduct Article IV, available at http://www.aicpa.org/Research/Standards/CodeofConduct/DownloadableDocuments/200 8CodeofProfessionalConduct.pdf

AICPA 1969. Ad Hoc Committee on Independence: Final Report in Journal of Accountancy (December 1969).

AICPA, 1997. Serving the Public Interest - A New Conceptual Framework for Auditor Independence, October 20, 1997, American Institute of Certified Public Accountants, New York.

Antle, R. 1984. Auditor Independence. Journal of Accounting Research 22 (1):1-20.

Antle, R., E. Gordon, G. Narayanamoorthy, and L. Zhou. 2006. The joint determination of Audit fees, non-audit fees, and abnormal accruals. Review of Quantitative Finance and Accounting 27(3): 235-266.

Arrunada, B. 1999. The Provision of Non-Audit Services by Auditors: Let the Market Evolve and Decide. International Review of Law and Economics 19(4):513-31.

Ashbaugh, H., R. LaFond, and B. W. Mayhew. 2003. Do Nonaudit Services Compromise Auditor Independence? Further Evidence. The Accounting Review 78 (3):611-639.

Ball, R., and L. Shivakumar. 2008. Earnings Quality at Initial Public Offerings. Journal of Accounting and Economics, 45(2-3): 324-349.

Beck, P., T. J. Frecka, and I. Solomon. 1988a. An Empirical Analysis of the Relationship Between MAS Involvement and Auditor Tenor: Implications for Auditor Independence. Journal of Accounting Literature 7:65-84.

1988b. A Model of the Market for MAS and Audit Services: Knowledge Spillovers and Auditor-Auditee Bonding. Journal of Accounting Literature 7:50-64.

Benston, G. J. 1975. Accountant's Integrity and Financial Reporting. Financial Executive 43 (8):10-14.

Bowman, A. W. 1985. Statement reproduced in SEC and Corporate Audits (Part 1), Hearings before the Subcommittee on Oversight and Investigations of the Committee on Energy and Commerce, House of Representatives, 99th Congress, 1st Session, March 6, 1985: 700.719. Washington, D.C.: Government Printing Office.

Briloff, A.J. 1972. Unaccountable Accounting. Harper \& Row, New York (1972).

Brown, J., D. Falaschetti and M.Orlando. 2010. Auditor Independence and Quality of Information in Financial Disclosure: Evidence for Market Discipline vs. Sarbanes-Oxley Proscriptions. American Law and Economics Review 12 (1): 39-68 
Brown, L. D. 2001. A Temporal Analysis of Earnings Surprises: Profits versus Losses. Journal of Accounting Research 39 (2):221-241.

Brown, L. D., and M. L. Caylor. 2005. A Temporal Analysis of Quarterly Earnings Thresholds: Propensities and Valuation Consequences. The Accounting Review 80 (2):423-440.

Burgstahler, D., and I. D. Dichev. 1997. Earnings Management to Avoid Earnings Decreases and Losses. Journal of Accounting and Economics 24 (1):99-126.

Chung, H., and S. Kallapur. 2003. Client Importance, Nonaudit Services, and Abnormal Accruals. The Accounting Review 78 (4):931-955.

Cohen Commission: The Commission on Auditors Responsibilities. 1978. Report, Conclusions, and Recommendations. New York, NY: The Commission on Auditors Responsibilities.

DeBerg, C. L., S. E. Kaplan, and K. Pany. 1991. An Examination of Some Relationships Between Non-Audit Services and Auditor Change. Accounting Horizons 5 (1):17-28.

Dechow, P. M., R. G. Sloan, and A. P. Sweeney. 1995. Detecting Earnings Management. The Accounting Review 70 (2):193-225.

DeFond, M. L., K. Raghunandan, and K. R. Subramanyam. 2002. Do Non-Audit Service Fees Impair Auditor Independence? Evidence from Going Concern Audit Opinions. Journal of Accounting Research 40 (4):1247-1274.

Degeorge, F., J. Patel and R. Zeckhauser. 1999. Earnings Manipulation to Exceed Thresholds. Journal of Business: 1-33.

Dopuch, N., R. R. King, and R. Schwartz. 2003. Independence in appearance and in fact: An empirical investigation. Contemporary Accounting Research 65: 83-113.

Firth, M. 1997. The Provision of Nonaudit Services by Accounting Firms to their Audit Clients. Contemporary Accounting Research 14 (2):1-21.

Francis, J. R. 2006. Are Auditors Compromised by Nonaudit Services? Assessing the Evidence. Contemporary Accounting Research 23 (3):747-760.

Francis, J. R., and B. Ke. 2006. Disclosures of Fees paid to Auditors and the Market Valuation of Earnings Surprises. Review of Accounting Studies 11 (4):495-523.

Frankel, R. M., M. F. Johnson, and K. K. Nelson. 2002. The Relation between Auditors' Fees for Nonaudit Services and Earnings Management. The Accounting Review 77 (Supplement):71-105.

Gleason, C. and L. Mills. 2011. Do Auditor-Provided Tax Services Improve the Estimate of Tax Expense? Contemporary Accounting Research, Forthcoming.

Glezen, G. W., and J. A. Millar. 1985. An Empirical Investigation of Stockholder Reaction to Disclosures Required by ASR No. 250. Journal of Accounting Research 23 (2):859-870. 
Graham, J. R., C. R. Harvey, and S. Rajgopal. 2005. The Economic Implications of Corporate Financial Reporting. Journal of Accounting and Economics 40(1-3):3-74.

Hayes, T. C. 1979. Accountants under scrutiny: Consulting jobs called risk to independence. The New York Times (June 25).

Hermalin, B. E., and M. S. Weisbach. 2003. Board of Directors as an Endogenously-Determined Institution: A Survey of the Economic Literature. Economic Policy Review 9 (1):7-26.

Hribar, P., and D. W. Collins. 2002. Errors in Estimating Accruals: Implications for Empirical Research. Journal of Accounting Research 40 (1):105-134.

Hribar, P., and D. C. Nichols. 2007. The Use of Unsigned Earnings Quality Measures in Tests of Earnings Management. Journal of Accounting Research 45 (5):1017-1053.

Jones, J. J. 1991. Earnings Management During Import Relief Investigations. Journal of Accounting Research 29 (2):193-228.

Kinney, W. R. 1988. Attestation research opportunities: 1987. Contemporary Accounting Research 4 (Spring): 416-25.

Kinney, W. R. 2005. Twenty-Five Years of Audit Deregulation and Re-Regulation: What Does it Mean for 2005 and Beyond? Auditing: A Journal of Practice and Theory 24 (Supplement):89-109.

Kinney, W. R., and R. Libby. 2002. Discussion of The Relation between Auditors' Fees for Nonaudit Services and Earnings Management. The Accounting Review 77 (Supplement):107-114.

Kinney, W. R., Z.-V. Palmrose, and S. Scholz. 2004. Auditor Independence, Non-Audit Services, and Restatements: Was the U.S. Government Right? Journal of Accounting Research 42 (3):561-588.

Klein, B. and K. B. Leffler. 1981. The Role of Market Forces in Assuring Contractual Performance. Journal of Political Economy 89: 615-41.

Larcker, D. F., and S. A. Richardson. 2004. Fees Paid to Audit Firms, Accrual Choices, and Corporate Governance. Journal of Accounting Research 40 (3): 625-658.

Levitt, A. 1998. The Numbers Game. Unpublished Remarks: Available at http://www.sec.gov/news/speech/speecharchive/1998/spch220.txt.

Maher M.W., Tiessen P, Colson R., and Broman A.J.(1992), “Competition and Audit Fees”, The Accounting Review, 67 (1): 199-211.

Matsumoto, D. A. 2002. Management's Incentives to Avoid Negative Earnings Surprises. The Accounting Review 77 (3):483-514.

Mautz, R. K., and H. A. Sharaf. 1961. The Philosophy of Auditing. Monograph No. 6. Sarasota, FL: American Accounting Association. 
Metcalf Committee Staff Study, 1977. Subcommittee on Reports Accounting and Management, Committee on Government Affairs, United States Senate, $95^{\text {th }}$ Congress, $1^{\text {st }}$ Session, 1977. Improving the Accountability of Publicly Owned Corporations and Their Auditors.

Mergenthaler, Richard D, Rajgopal, Shivaram and Srinivasan, Suraj., 2011. CEO and CFO Career Penalties to Missing Quarterly Analysts Forecasts. Working Paper, University of Iowa, Emory University, and Harvard Business School.

Palmrose, Z.-V. 1999. Empirical research on auditor litigation: Considerations and Data. Studies in Accounting Research Monograph \#33, Sarasota, FL: AAA.

Parkash, M., and C. F. Venable. 1993. Auditee Incentives for Auditor Independence: The Case of Nonaudit Services. The Accounting Review 68 (1):113-133.

Public Oversights Board (POB). 2000. Panel on Audit Effectiveness: Report and Recommendations. Stamford CT: American Institute of Certified Public Accountants.

Previts, G. J. 1985. The Scope of CPA Services - A Study of the Development of the Concept of Independence and the Profession's Role in Society. John Wiley \& Sons.

Report of the Special Committee on Equity Funding. 1975. New York, NY: American Institute of Certified Public Accountants.

Reynolds, J. K., D. R. Deis, and J. R. Francis. 2004. Professional Service Fees and Auditor Objectivity. Auditing: A Journal of Practice and Theory 23 (1):29-52.

Ruddock, C., S. J. Taylor, and S. L. Taylor. 2006. Nonaudit Services and Earnings Conservatism: Is Auditor Independence Impaired? Contemporary Accounting Research 23 (3):701-746.

Scheiner, J. H. 1984. An Empirical Assessment of the Impact of SEC Nonaudit Service Disclosure Requirements on Independent Auditors and Their Clients. Journal of Accounting Research 22 (2):789-797.

Scheiner, J. H., and J. E. Kiger. 1982. An Empirical Investigation of Auditor Involvement in Non-Audit Services. Journal of Accounting Research 20 (2):482-496.

Securities Exchange Commission (SEC). 1978. Accounting Series Release No. 250: Disclosure of Relationships with Independent Public Accounts. Washington D.C.: Government Printing Office.

- 2000. Final Rule: Revision of the Commission's Auditor Independence Requirements. Washington D.C.: Government Printing Office.

Seidler, L. J., F. Andrews, and M. J. Epstein. 1977. The Equity Funding Papers: The Anatomy of a Fraud. Santa Barbara, CA: Wiley/Hamilton.

Simunic, D. A. 1984. Auditing, Consulting, and Auditor Independence. Journal of Accounting Research 22 (2):679-702.

Stevens, M. 1991. The Big Six - The Selling Out of America’s Top Accounting Firms. Simon \& Schuster. 
Teoh, S. H., I. Welch, and T. J. Wong. 1998. Earnings Management and the Underperformance of Seasoned Equity Offerings. Journal of Financial Economics 50 (1):63-99.

Warfield, T. D., J. J. Wild, and K. L. Wild. 1995. Managerial Ownership, Accounting Choices, and Informativeness of Earnings. Journal of Accounting and Economics 20 (1):61-91.

Watts, R. L., and J. L. Zimmerman. 1981. The Markets for Independence and Independent Auditors. Working paper, University of Rochester.

- 1983. Agency Problems, Auditing, and the Theory of the Firm: Some Evidence. Journal of Law and Economics 26 (3):613-633.

Whisenant, S., S. Sankaraguruswamy, and K. Raghunandan. 2003. Evidence on the Joint Determination of Audit and Non-Audit Fees. Journal of Accounting Research 41 (4): 721-744.

Zeff, S. 2003. How the U.S. accounting profession got where it is today: Part I. Accounting Horizons17 (3): 189-205. 
Table 1: Sample Descriptive Statistics

Panel A: Non-Audit Service Fee Descriptive Statistics

\begin{tabular}{l|cccccc}
\hline \multicolumn{1}{c|}{ Variable } & $\begin{array}{c}\text { No. of non- } \\
\text { zero obs }\end{array}$ & Mean & Median & $\begin{array}{c}\text { Standard } \\
\text { Deviation }\end{array}$ & $\begin{array}{c}\mathbf{2 5}^{\text {th }} \\
\text { Percentile }\end{array}$ & $\begin{array}{c}\mathbf{7 5}^{\text {th }} \\
\text { Percentile }\end{array}$ \\
\hline NAS & 1281 & 0.175 & 0.145 & 0.125 & 0.091 & 0.237 \\
IS & 316 & 0.146 & 0.083 & 0.159 & 0.044 & 0.187 \\
Tax & 1011 & 0.116 & 0.097 & 0.085 & 0.057 & 0.153 \\
M\&A & 187 & 0.089 & 0.059 & 0.079 & 0.038 & 0.107 \\
HR & 235 & 0.061 & 0.048 & 0.035 & 0.038 & 0.083 \\
Legal & 47 & 0.069 & 0.065 & 0.037 & 0.038 & 0.084 \\
Other Consulting & 264 & 0.085 & 0.057 & 0.080 & 0.038 & 0.099 \\
Other Service & 713 & 0.050 & 0.038 & 0.039 & 0.021 & 0.065 \\
& & & & & & \\
\hline
\end{tabular}

Notes: NAS refers to total non-audit fees as a percentage of total service fees. IS refers to the assistance in accounting systems installation and review, including all systems and accounting related technology services provided by the auditor to the company. Tax refers to total tax total of all tax related services. Tax services include (i) tax services provided specifically for Directors and Officers of the company, (ii) tax consulting and planning services provided directly to the company itself, (iii) tax preparation review, and (iv) assistance with IRS examination to the company itself. M\&A refers to acquisition and divesture assistance that the auditor provided for any contemplated or realized company acquisitions, including sales of either divisions or subsidiaries. HR refers to the planning and examination of employee benefit plans, including fees for the planning and examination of all employee retirement, pension, and benefit related services. Legal refers to legal services and assistance rendered to the company by the auditor. Other Consulting includes any consulting services (larger that 3\%) that do not fit into any of the preceding categories. Other Services include services that on the proxy statements are shown in aggregate as a total, all together represents less than 3\% of audit fees. 
Table 1: Sample Descriptive Statistics (cont'd)

Panel B: Firm Descriptive Statistics

\begin{tabular}{|c|c|c|c|c|c|c|}
\hline Variable & No. of Obs & Mean & Median & $\begin{array}{l}\text { Standard } \\
\text { Deviation }\end{array}$ & $\begin{array}{c}25^{\text {th }} \\
\text { Percentile }\end{array}$ & $\begin{array}{c}75^{\text {th }} \\
\text { Percentile }\end{array}$ \\
\hline LnTA & 1281 & 7.401 & 7.471 & 1.337 & 6.439 & 8.208 \\
\hline LnMVE & 1279 & 6.489 & 6.568 & 1.266 & 5.721 & 7.247 \\
\hline MB & 1276 & 1.198 & 0.981 & 0.734 & 0.712 & 1.464 \\
\hline LEV & 1281 & 0.183 & 0.177 & 0.123 & 0.086 & 0.265 \\
\hline ROA & 1281 & 0.074 & 0.069 & 0.050 & 0.043 & 0.102 \\
\hline DumROA $^{+}$ & 1281 & 0.965 & 1.000 & 0.184 & 1.000 & 1.000 \\
\hline RET & 1262 & 0.011 & -0.019 & 0.266 & -0.176 & 0.181 \\
\hline DumRET $^{-}$ & 1262 & 0.517 & 1.000 & 0.500 & 0.000 & 1.000 \\
\hline RISK & 1262 & 1.080 & 1.075 & 0.390 & 0.808 & 1.321 \\
\hline EARNINGS & 1272 & 0.139 & 0.147 & 0.126 & 0.103 & 0.194 \\
\hline VAR & 1273 & 0.660 & 0.309 & 1.090 & 0.171 & 0.661 \\
\hline PERS & 1273 & 0.320 & 0.300 & 0.380 & 0.039 & 0.622 \\
\hline DumLOSS & 1281 & 0.040 & 0.000 & 0.196 & 0.000 & 0.000 \\
\hline DumSURP & 1274 & 0.261 & 0.000 & 0.440 & 0.000 & 1.000 \\
\hline ACC & 1281 & -0.026 & -0.026 & 0.061 & -0.059 & 0.007 \\
\hline DumACC $^{+}$ & 1281 & 0.301 & 0.000 & 0.459 & 0.000 & 1.000 \\
\hline |DACC $\mid$ & 1271 & 0.043 & 0.031 & 0.042 & 0.014 & 0.058 \\
\hline CFO & 1281 & 0.099 & 0.095 & 0.075 & 0.056 & 0.135 \\
\hline DumCFO $^{+}$ & 1281 & 0.931 & 1.000 & 0.254 & 1.000 & 1.000 \\
\hline CFOVOL & 1275 & 0.037 & 0.027 & 0.035 & 0.018 & 0.041 \\
\hline DumACQ & 1281 & 0.232 & 0.000 & 0.422 & 0.000 & 0.000 \\
\hline DumISSUE & 1281 & 0.076 & 0.000 & 0.265 & 0.000 & 0.000 \\
\hline DumLitigation & 1281 & 0.456 & 0.000 & 0.498 & 0.000 & 1.000 \\
\hline Governance & 1281 & 0.509 & 0.508 & 0.286 & 0.259 & 0.757 \\
\hline
\end{tabular}




\section{Table 1: Sample Descriptive Statistics (cont'd)}

Notes: All data item numbers refer to the annual Compustat tapes, unless otherwise mentioned.

LnTA is the natural logarithm of total assets (\#6). LnMVE is the natural logarithm of market value of equity, computed as the computed as the closing price at fiscal year-end (\#199) multiplied by common shares outstanding (\#25). MB is the market-to-book ratio (\#199* \#25 / \#60). LEV refers to leverage, computed as the ratio of long-term debt (\#9) to total assets (\#6). INVREC is the sum of inventory (\#3) and accounts receivable (\#2), scaled by begging-of-year total assets. ROA refers to return-on-assets, computed as the ratio of earnings before extraordinary items (\#18) to beginning-of-year total assets (\#6). DumROA ${ }^{+}$ is a dummy set to 1 if ROA is positive. RET is market-adjusted annual stock returns. DumRET is a dummy set to 1 if RET is negative. RISK refers to the firm's systematic risk, computed using monthly returns for five years ending with the year of observation. EARNINGS represent earnings before extraordinary items (\#18) scaled by beginning-of-year market value (\#199*\#25). VAR is the variability of earnings for the 16 quarters ending with the year of observation. PERS is the persistence of earnings, computed as the firstorder autocorrelation in earnings for 16 quarters ending with the year of observation. DumLOSS is a dummy set to 1 if the firm reports a negative net income (\#172). DumSURP is a dummy set to 1 if the firm reports a small increase in earnings, measured as the change in net income (\#172) scaled by beginning-ofyear total assets (\#6) fall within the range of 0.00 to 0.01 . ACC is total accruals scaled by beginning-of-year total assets, where accruals are computed using the balance sheet method as changes in working capital [ $\Delta$ current assets (\#4) - $\Delta$ current liabilities ( $\# 5)$ - $\Delta$ cash (\#1) $+\Delta$ short-term debt (\#34) -depreciation (\#14)]. DumACC ${ }^{+}$is a dummy set to 1 if the total accruals are positive. |DACC| is the absolute value of discretionary accruals, computed using the modified Jones (1991) method as described in the text. CFO is operating cash flows scaled by beginning-of-year total assets, computed as earnings before extraordinary items (\#18) less total accruals. DumCFO ${ }^{+}$is a dummy variable set to 1 if the firm's CFO is positive. CFOVOL is cash flow volatility, computed as the standard deviation of operating cash flow for the 16 quarters ending with the year of observations. DumACQ is a dummy set to 1 if the firm engages in cash acquisition of another firm (\#129 > 0) during the year. DumISSUE is a dummy set to 1 if the firm issues significant additional equity during the year, as indicated by at least $10 \%$ increase over the previous year in the number of shares outstanding (\#25), adjusted for splits and dividends(\#27). DumLitigation is a dummy set to 1 if the firm is in a highly-litigious industry, as identified from the auditor litigation database (Palmrose 1999). Industries include mining (SIC2 code 13), manufacturing (SIC2 code 20, 33 to 37), retailing (SIC2 code 52 to 59) and financial (SIC2 code 61 to 66). Governance refers to a ranked index of the firm's corporate governance, based on (i) whether if the CEO is also the Chairman, (ii) board size and (iii) ratio of external board members to total board size. 
Table 2: Non-Audit Service Fees and Absolute Discretionary Accruals

$\left|\mathrm{DACC}_{i, t}\right|=\beta_{0}+\beta_{1} N A S_{i, t-1}+\beta_{2}$ LnTA $_{i, t-1}+\beta_{3} \mathrm{CFO}_{i, t-1}+\beta_{4}$ DumCFO $_{i, t-1}^{+}+\beta_{5}$ ACC $_{i . t-1}$ $+\beta_{6}$ DumACC $_{i, t-1}^{+}+\beta_{7}$ ROA $_{i, t-1}+\beta_{8}$ DumROA $_{i, t-1}^{+}+\beta_{9}$ DumACQ $_{i, t}+\beta_{10}$ DumISSUE $_{i, t}$ $+\beta_{11} M_{i, t-1}+\beta_{12} L_{E V} V_{i, t-1}+\beta_{13}$ CFOVOL $_{i, t}+\beta_{14}$ DumLitigation $_{i, t}$

$+\gamma$ IndustryDummies $_{i, t}+\delta$ YearDummies $_{t}+\varepsilon_{t}$

\begin{tabular}{|c|c|c|c|c|}
\hline \multirow[t]{2}{*}{ Variable } & \multicolumn{2}{|c|}{$\begin{array}{c}\text { NAS } \\
\text { (1) }\end{array}$} & \multicolumn{2}{|c|}{$\begin{array}{l}\text { ISFEE } \\
\text { (2) }\end{array}$} \\
\hline & Coeff & (t-stat) & Coeff & (t-stat) \\
\hline NAS & -0.007 & $(-0.76)$ & -0.018 & $(-1.81)^{*}$ \\
\hline LnTA & -0.005 & $(-3.08) * * *$ & -0.004 & $(-3.04)^{* * *}$ \\
\hline CFO & -0.242 & $(-1.89)^{*}$ & -0.237 & $(-1.86)$ \\
\hline DumCFO $^{+}$ & -0.003 & $(-0.40)$ & -0.003 & $(-0.37)$ \\
\hline ACC & -0.338 & $(-2.35)^{* *}$ & -0.332 & $(-2.33)^{* *}$ \\
\hline DumACC $^{+}$ & 0.007 & $(1.86)^{*}$ & 0.007 & $(1.91)^{*}$ \\
\hline ROA & 0.200 & $(1.52)$ & 0.195 & (1.49) \\
\hline DumROA $^{+}$ & -0.006 & $(-0.50)$ & -0.006 & $(-0.54)$ \\
\hline DumACQ & 0.000 & $(0.17)$ & 0.001 & $(0.24)$ \\
\hline DumISSUE & 0.009 & $(1.81)^{*}$ & 0.010 & $(1.85)^{*}$ \\
\hline MB & 0.004 & $(7.22)^{* * *}$ & 0.004 & $(7.02)^{* * *}$ \\
\hline LEV & -0.024 & $(-1.74)^{*}$ & -0.023 & $(-1.65)^{*}$ \\
\hline CFOVOL & 0.248 & $(4.37)^{* * *}$ & 0.250 & $(4.37) * * *$ \\
\hline DumLitigation & 0.072 & $(4.15)^{* * *}$ & 0.071 & $(4.21) * * *$ \\
\hline $\begin{array}{l}\text { No. of firm- } \\
\text { year obs }\end{array}$ & & 60 & & 60 \\
\hline Adjusted R²(\%) & & & & \\
\hline
\end{tabular}


Table 2: Non-Audit Service Fees and Absolute Discretionary Accruals (cont’d)

Notes: SIC2 Industry Dummies and Year Dummies are not reported for brevity. NAS refers to total nonaudit fees as a percentage of total service fees. ISFEE is the percentage of information service fee to total service fees, where IS refers to the assistance of installing and reviewing accounting systems, including all systems and accounting related technology services provided by the auditor to the firm. $|\mathrm{DACC}|$ is the absolute value of discretionary accruals, computed using the modified Jones (1991) method. LnTA is the natural logarithm of total assets. CFO is operating cash flows scaled by beginning-of-year total assets. DumCFO $^{+}$is a dummy variable set to 1 if the firm's CFO is positive. ACC is total accruals scaled by beginning-of-year total assets. DumACC ${ }^{+}$is a dummy set to 1 if the total accruals are positive. ROA refers to return-on-assets. DumROA ${ }^{+}$is a dummy set to 1 if ROA is positive. DumACQ is a dummy set to 1 if the firm engages in cash acquisition of the firm during the year. DumISSUE is a dummy set to 1 if the firm issues significant additional equity during the year, as indicated by at least $10 \%$ increase over the previous year in the number of shares outstanding, adjusted for splits and dividends. MB is the market-to-book ratio. $\mathrm{LEV}$ refers to leverage, computed as the ratio of long-term debt to total assets. CFOVOL is cash flow volatility, computed as the standard deviation of operating cash flow for the 16 quarters ending with the year of observations. *, **, *** indicates significance level (2-tailed) at 10\%, 5\% and 1\% respectively. tstats are based on standard errors clustered by firm. DumLitigation is a dummy set to 1 if the firm is in a highly-litigious industry, as identified from the auditor litigation database (Palmrose 1999). Industries include mining (SIC2 code 13), manufacturing (SIC2 code 20, 33 to 37), retailing (SIC2 code 52 to 59) and financial (SIC2 code 61 to 66). 
Table 3: Non-Audit Service Fees and the Propensity to Achieve Small Earnings Surprises

$$
\begin{aligned}
& \text { DumSurp }_{i, t}=\beta_{0}+\beta_{1} \text { NAS }_{i, t-1}+\beta_{2} \text { LnTA }_{i, t-1}+\beta_{3} \text { CFO }_{i, t-1}+\beta_{4} \text { ROA }_{i, t-1}+\beta_{5} \text { DumROA }_{i, t-1}^{+} \\
& +\beta_{6} \text { DumACQ }_{i, t}+\beta_{7} \text { DumISSUE }_{i, t}+\beta_{8} M_{i, t-1}+\beta_{9} \text { DumLitigation }_{i, t} \\
& +\gamma \text { IndustryDummies }_{i, t}+\text { SYearDummies }_{t}+\varepsilon_{t}
\end{aligned}
$$

\begin{tabular}{|c|c|c|c|c|}
\hline \multirow[t]{2}{*}{ Variable } & \multicolumn{2}{|r|}{$\begin{array}{l}\text { NAS } \\
(1)\end{array}$} & \multicolumn{2}{|r|}{$\begin{array}{c}\text { ISFEE } \\
\text { (2) }\end{array}$} \\
\hline & Coeff & $\left(\chi^{2}\right.$-stat $)$ & Coeff & ( $\chi^{2}$-stat $)$ \\
\hline NAS & -1.079 & (3.59)* & -1.520 & $(5.14)^{* *}$ \\
\hline LnTA & 0.334 & $(35.50)^{* * *}$ & 0.326 & $(34.69) * * *$ \\
\hline CFO & -1.314 & (1.37) & -1.329 & (1.36) \\
\hline ROA & -9.198 & $(12.20) * * *$ & -9.029 & $(11.82) * * *$ \\
\hline DumROA $^{+}$ & 2.888 & $(13.25) * * *$ & 2.883 & $(13.40) * * *$ \\
\hline DumACQ & 0.211 & (1.49) & 0.204 & (1.39) \\
\hline DumISSUE & -0.090 & $(0.14)$ & -0.060 & $(0.06)$ \\
\hline MB & 0.059 & (0.19) & 0.032 & $(0.06)$ \\
\hline DumLitigation & -0.201 & $(2.01)$ & -0.193 & $(1.86)$ \\
\hline No. of firm-year obs & & 1266 & & 1266 \\
\hline Pseudo R²(\%) & & 0.137 & & 0.137 \\
\hline
\end{tabular}

Notes: SIC2 Industry Dummies and Year Dummies are not reported for brevity. NAS refers to total nonaudit fees as a percentage of total service fees. ISFEE is the percentage of information service fee to total service fees, where IS refers to the assistance of installing and reviewing accounting systems, including all systems and accounting related technology services provided by the auditor to the firm. DumSURP is a dummy set to 1 if the firm reports a small increase in earnings, measured as the change in net income scaled by beginning-of-year total assets (\#6) fall within the range of 0.00 to 0.01 . LnTA is the natural logarithm of total assets. LnMVE is the natural logarithm of market value of equity. CFO is operating cash flows scaled by beginning-of-year total assets, computed as earnings less accruals. ROA refers to returnon-assets, computed as the ratio of earnings to beginning-of-year total assets. DumROA ${ }^{+}$is a dummy set to 1 if ROA is positive. RET is market-adjusted cumulative abnormal returns. DumACQ is a dummy set to 1 if the firm engages in cash acquisition of the firm during the year. DumISSUE is a dummy set to 1 if the firm issues significant additional equity during the year, as indicated by at least $10 \%$ increase over the previous year in the number of shares outstanding, adjusted for splits and dividends. MB is the market-tobook ratio. ${ }^{*},{ }^{* *},{ }^{* * *}$ indicates significance level at $10 \%, 5 \%$ and $1 \%$ respectively. DumLitigation is a dummy set to 1 if the firm is in a highly-litigious industry, as identified from the auditor litigation database (Palmrose 1999). Industries include mining (SIC2 code 13), manufacturing (SIC2 code 20, 33 to 37), retailing (SIC2 code 52 to 59) and financial (SIC2 code 61 to 66). 
Table 4: Non-Audit Service Fees and Earnings Association

$$
\begin{aligned}
& \text { RET } \left._{i, t}=\beta_{0}+\beta_{1} \text { Earnings }_{i, t}+\beta_{2} \text { Earnings }_{i, t} * N A S_{i, t-1}\right)+\beta_{3}\left(\text { Earnings }_{i, t} * \text { LnTA }_{i, t-1}\right) \\
& +\beta_{4}\left(\text { Earnings }_{i, t} * \text { Risk }_{i, t}\right)+\beta_{5}\left(\text { Earnings }_{i, t} * \text { LEV }_{i, t-1}\right)+\beta_{6}\left(\text { Earnings }_{i, t} * M B_{i, t-1}\right) \\
& +\beta_{7}\left(\text { Earnings }_{i, t} * \operatorname{VAR}_{i, t}\right)+\beta_{8}\left(\text { Earnings }_{i, t} * P E R S_{i, t}\right)+\gamma \text { IndustryDummies }_{i, t} \\
& + \text { SearDummies }_{t}+\varepsilon_{t}
\end{aligned}
$$

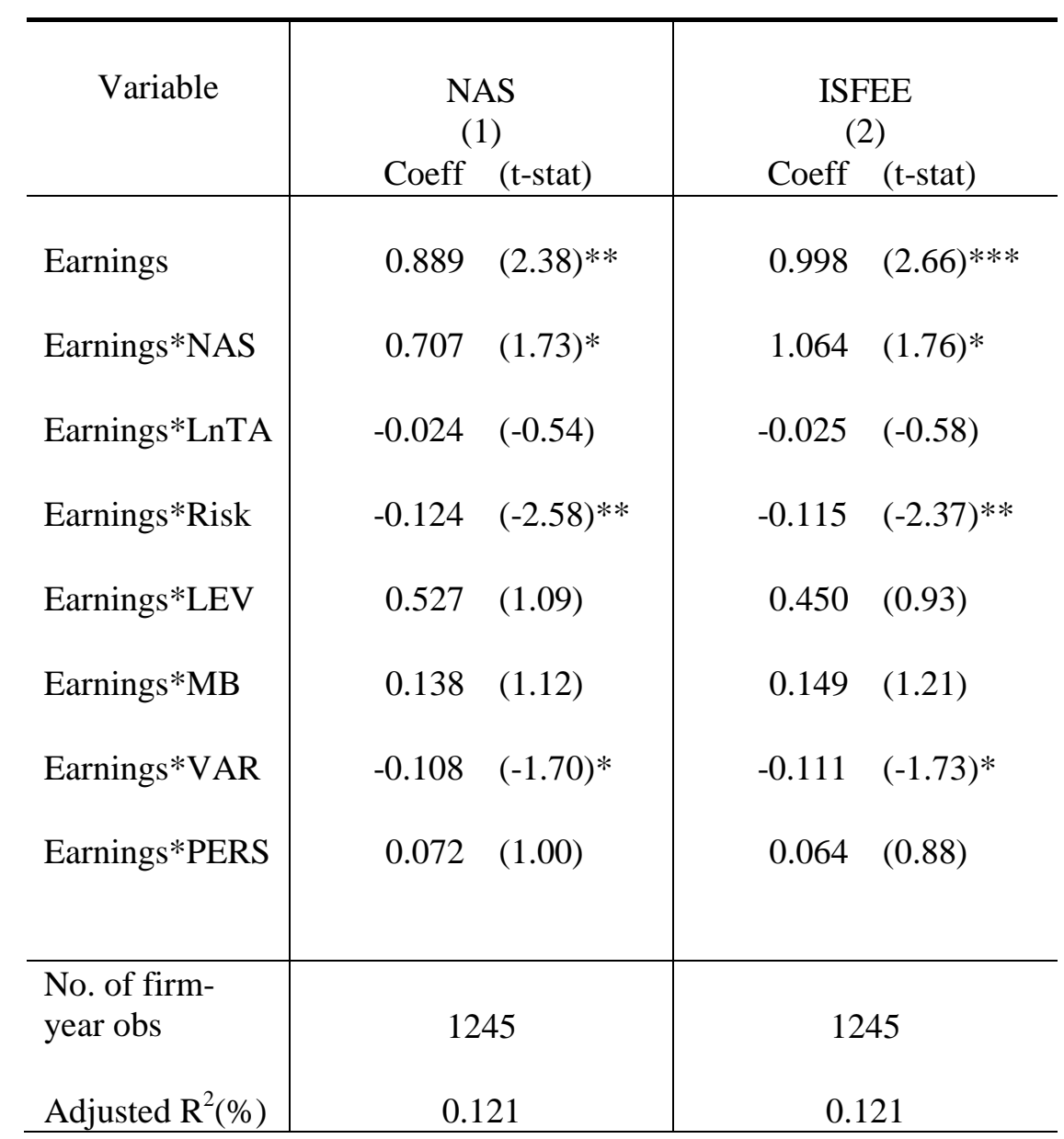

Notes: SIC2 Industry Dummies and Year Dummies are not reported for brevity. NAS refers to total nonaudit fees as a percentage of total service fees. ISFEE is the percentage of information service fee to total service fees, where IS refers to the assistance of installing and reviewing accounting systems, including all systems and accounting related technology services provided by the auditor to the firm. RET is marketadjusted stock returns beginning from fiscal month 4 and ending in the following year fiscal month 3. EARNINGS represent earnings before extraordinary items scaled by beginning-of-year market value. LnTA is the natural logarithm of total assets. RISK refers to the firm's systematic risk, computed using monthly returns for five years ending with the year of observation. LEV refers to leverage, computed as the ratio of long-term debt to total assets. MB is the market-to-book ratio. VAR is the variability of earnings for the 16 quarters ending with the year of observation. PERS is the persistence of earnings, computed as the first-order autocorrelation in earnings for 16 quarters ending with the year of observation. *, **, *** indicates significance level (2-tailed) at 10\%, 5\% and 1\% respectively. t-stats are based on standard errors clustered by firm. 
Table 5 -- Cumulative Abnormal Returns surrounding the events relating to rescission of ASR 250

Panel A: Univariate Analysis

\begin{tabular}{|c|c|c|c|c|c|c|c|}
\hline $\begin{array}{c}\text { Mean } \\
\text { (t-value) }\end{array}$ & $\begin{array}{l}\text { Overall } \\
\text { Sample } \\
n=436\end{array}$ & $\begin{array}{c}\text { High } \\
\text { NAS } \\
\mathbf{n}=221\end{array}$ & $\begin{array}{c}\text { Low } \\
\text { NAS } \\
\mathbf{n}=\mathbf{2 1 5}\end{array}$ & Difference & $\begin{array}{c}\text { ISFEE } \\
n=100\end{array}$ & $\begin{array}{c}\text { No } \\
\text { ISFEE } \\
\mathbf{n}=336\end{array}$ & Difference \\
\hline $\begin{array}{c}\text { Event } 1 \\
\text { 8/20/1981 }\end{array}$ & $\begin{array}{c}0.002 \\
(1.73)^{*}\end{array}$ & $\begin{array}{l}0.003 \\
(1.58)\end{array}$ & $\begin{array}{l}0.001 \\
(0.82)\end{array}$ & $\begin{array}{l}0.002 \\
(0.62)\end{array}$ & $\begin{array}{l}0.004 \\
(1.46)\end{array}$ & $\begin{array}{l}0.002 \\
(1.16)\end{array}$ & $\begin{array}{l}0.002 \\
(0.80)\end{array}$ \\
\hline $\begin{array}{c}\text { Event } 2 \\
9 / 9 / 1981\end{array}$ & $\begin{array}{c}0.004 \\
(2.55)^{* *}\end{array}$ & $\begin{array}{c}0.006 \\
(2.94)^{* * *}\end{array}$ & $\begin{array}{l}0.002 \\
(0.74)\end{array}$ & $\begin{array}{l}0.004 \\
(1.41)\end{array}$ & $\begin{array}{c}0.005 \\
(1.95)^{*}\end{array}$ & $\begin{array}{c}0.003 \\
(1.89)^{*}\end{array}$ & $\begin{array}{l}0.002 \\
(0.68)\end{array}$ \\
\hline $\begin{array}{c}\text { Event } 3 \\
\text { 1/28/1982 }\end{array}$ & $\begin{array}{l}0.002 \\
(1.23)\end{array}$ & $\begin{array}{l}0.007 \\
(2.43)^{* *}\end{array}$ & $\begin{array}{l}-0.002 \\
(-0.88)\end{array}$ & $\begin{array}{l}0.009 \\
(0.62)\end{array}$ & $\begin{array}{l}0.041 \\
(1.15)\end{array}$ & $\begin{array}{l}0.002 \\
(0.74)\end{array}$ & $\begin{array}{l}0.003 \\
(0.75)\end{array}$ \\
\hline $\begin{array}{c}\text { Sum of } \\
\text { All Events }\end{array}$ & $\begin{array}{c}0.008 \\
(2.77)^{* * *}\end{array}$ & $\begin{array}{c}0.015 \\
(3.83)^{* * *}\end{array}$ & $\begin{array}{l}0.000 \\
(0.00)\end{array}$ & $\begin{array}{c}0.015 \\
(2.75)^{* * *}\end{array}$ & $\begin{array}{c}0.016 \\
(3.41)^{* * *}\end{array}$ & $\begin{array}{l}0.003 \\
(0.86)\end{array}$ & $\begin{array}{c}0.013 \\
(2.29)^{* *}\end{array}$ \\
\hline
\end{tabular}

Event 1 refers Aug 201981 when the SEC propose to rescind ASR250

Event 2 refers to Sep 9, 1981 when the SEC Practice Section requires NAS reporting privately to the AICPA

Event 3 refers to Jan 281982 when the SEC formally rescinded ASR250 
Table 5 -- Cumulative Abnormal Returns surrounding the events relating to rescission of ASR 250 (cont'd)

Panel B: Multivariate Analysis

$$
R E T_{i, t}=\beta_{0}+\alpha_{0} N A S(\text { or ISFEE })+\beta_{2} \text { Risk }_{i, t}+\beta_{3} \text { Size }_{i, t}+\beta_{4} M B_{i, t}+\varepsilon_{t}
$$

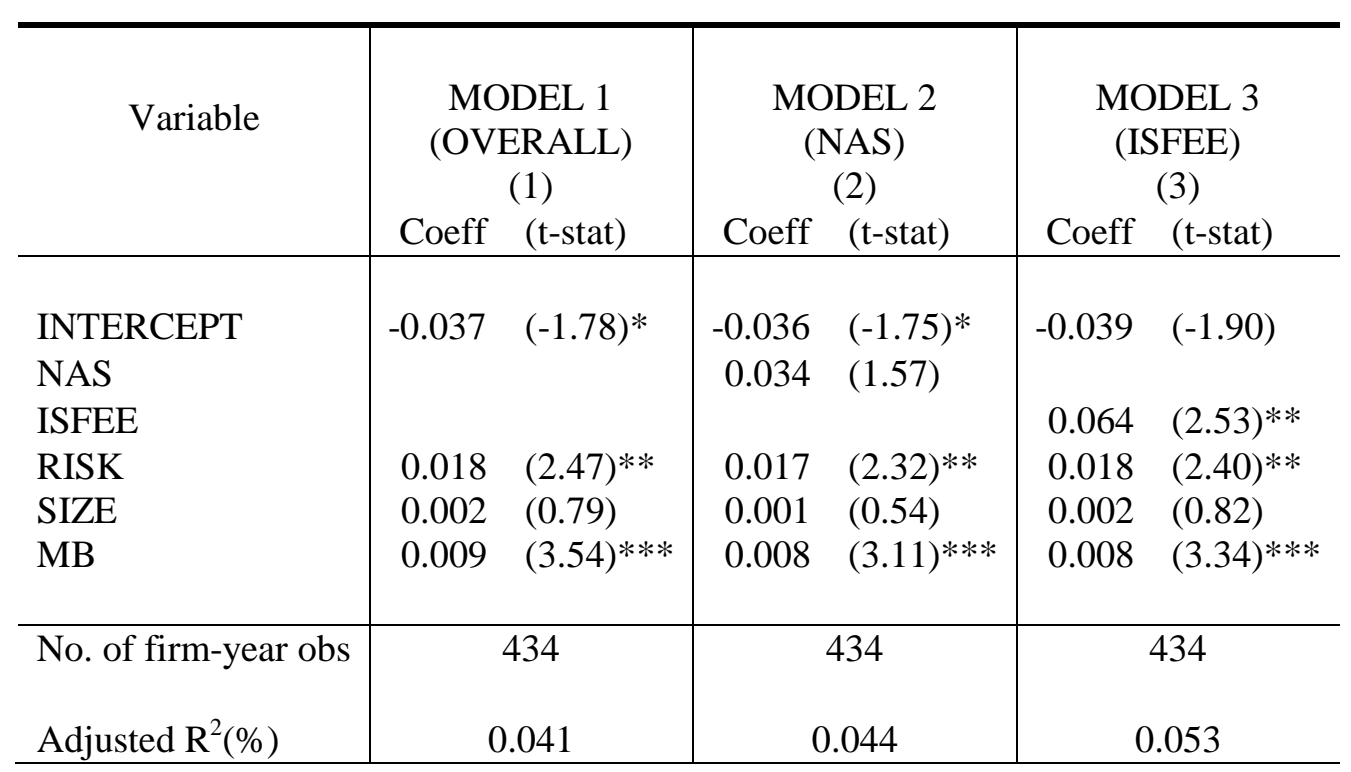

Notes: RET is the sum of the market-adjusted 3-day stock returns surrounding the three events relating to the rescission of ASR250. RISK refers to the firm's systematic risk, computed using monthly returns for five years ending with the year of observation. SIZE is computed using the natural logarithm of total assets. MB is the market-to-book ratio. NAS refers to total non-audit fees as a percentage of total service fees. ISFEE is the percentage of information service fee to total service fees, where IS refers to the assistance of installing and reviewing accounting systems, including all systems and accounting related technology services provided by the auditor to the firm. All other variables are as defined in previous tables. *,**,*** indicates significance level (2-tailed) at $10 \%, 5 \%$ and $1 \%$ respectively. 
Table 6: NAS and Earnings Quality after rescission of ASR 250

$$
\begin{aligned}
& \text { Panel A: NAS and Absolute Discretionary Accruals } \\
& \quad \text { DACC }_{i, t}=\beta_{0}+\beta_{1} \text { POST }_{i, t}+\beta_{2} \text { DumHighNAS }_{i, t}+\beta_{3}\left(\text { POST }_{i, t} * \text { DumHighNAS }_{i, t}\right)+\beta_{4} \text { DumCFO }_{i, t-1}^{+} \\
& +\beta_{5} \text { LnTA }_{i, t-1}+\beta_{6} \text { CFO }_{i, t-1}+\beta_{7} \text { DumCFO }_{i, t-1}^{+}+\beta_{8} \text { ACC }_{i, t-1}+\beta_{9} \text { DumACC }_{i, t-1}^{+}+\beta_{10} \text { ROA }_{i, t-1} \\
& +\beta_{11} \text { DumROA }_{i, t-1}^{+}+\beta_{12} \text { DumACQ }_{i, t}+\beta_{13} \text { DumISSUE }_{i, t}+\beta_{14} \text { MB }_{i, t-1}+\beta_{15} L_{E V_{i, t-1}}+\beta_{16} \text { CFOVOL }_{i, t} \\
& +\beta_{17} \text { DumLitigation }_{i, t}+\gamma \text { IndustryDummies }_{i, t}+\text { SYearDummies }_{t}+\varepsilon_{t}
\end{aligned}
$$

\begin{tabular}{|c|c|c|c|c|}
\hline \multirow[t]{2}{*}{ Variable } & \multicolumn{2}{|c|}{$\begin{array}{c}\text { NAS } \\
(1)\end{array}$} & \multicolumn{2}{|c|}{$\begin{array}{c}\text { ISFEE } \\
\text { (2) }\end{array}$} \\
\hline & Coeff & (t-stat) & Coeff & (t-stat) \\
\hline POST & 0.000 & $(-0.12)$ & 0.001 & $(0.21)$ \\
\hline DumHighNAS & 0.001 & $(0.20)$ & 0.005 & $(1.47)$ \\
\hline POST*DumHighNAS & -0.002 & $(-0.58)$ & -0.009 & $(-2.03)^{* *}$ \\
\hline LnTA & -0.003 & $(-2.32)^{* *}$ & -0.003 & $(-2.24)^{* *}$ \\
\hline CFO & 0.076 & $(2.26)^{* *}$ & -0.196 & $(-1.16)$ \\
\hline DumCFO $^{+}$ & -0.009 & $(-1.63)$ & -0.007 & $(-1.41)$ \\
\hline ACC & -0.026 & $(-4.35)^{* * *}$ & -0.324 & $(-1.89)^{*}$ \\
\hline DumACC $^{+}$ & 0.009 & $(2.43)^{* *}$ & 0.011 & $(3.10) * * *$ \\
\hline ROA & -0.132 & $(-3.38)^{* * *}$ & 0.148 & $(0.85)$ \\
\hline DumROA $^{+}$ & -0.006 & $(-0.89)$ & -0.005 & $(-0.75)$ \\
\hline DumACQ & 0.001 & $(0.52)$ & 0.001 & $(0.49)$ \\
\hline DumISSUE & 0.007 & $(1.85)^{*}$ & 0.008 & $(1.98)^{* *}$ \\
\hline MB & 0.003 & $(4.44)^{* * *}$ & 0.003 & $(4.10) * * *$ \\
\hline LEV & -0.010 & $(-0.75)$ & -0.010 & $(-0.70)$ \\
\hline CFOVOL & 0.346 & $(6.45)^{* * *}$ & 0.348 & $(6.54)^{* * *}$ \\
\hline DumLitigation & 0.006 & $(0.62)$ & 0.006 & $(0.60)$ \\
\hline No. of firm-year obs & & 677 & & \\
\hline Adjusted R²(\%) & & 981 & 0.2 & 002 \\
\hline
\end{tabular}


Table 6: NAS and Earnings Quality after rescission of ASR 250

Panel B: NAS and Propensity to Achieve Small Earnings Surprises

DumSurp $_{i, t}=\beta_{0}+\beta_{1}$ POST $_{i, t}+\beta_{2}$ DumHighNAS $_{i, t}+\beta_{3}\left(\right.$ POST $\left.^{*} \operatorname{DumHighNAS}_{i, t}\right)$

$+\beta_{4} \operatorname{LnTA}_{i, t-1}+\beta_{5}$ CFO $_{i, t-1}+\beta_{6}$ ROA $_{i, t-1}+\beta_{7}$ DumROA $_{i, t-1}^{+}+\beta_{8} \operatorname{DumACQ}_{i, t}$

$+\beta_{9}$ DumISSUE $_{i, t}+\beta_{10}$ MB $_{i, t-1}+\beta_{11}$ DumLitigation $_{i, t}+\gamma$ IndustryDummies $_{i, t}+$ SYearDummies $_{t}+\varepsilon_{t}$

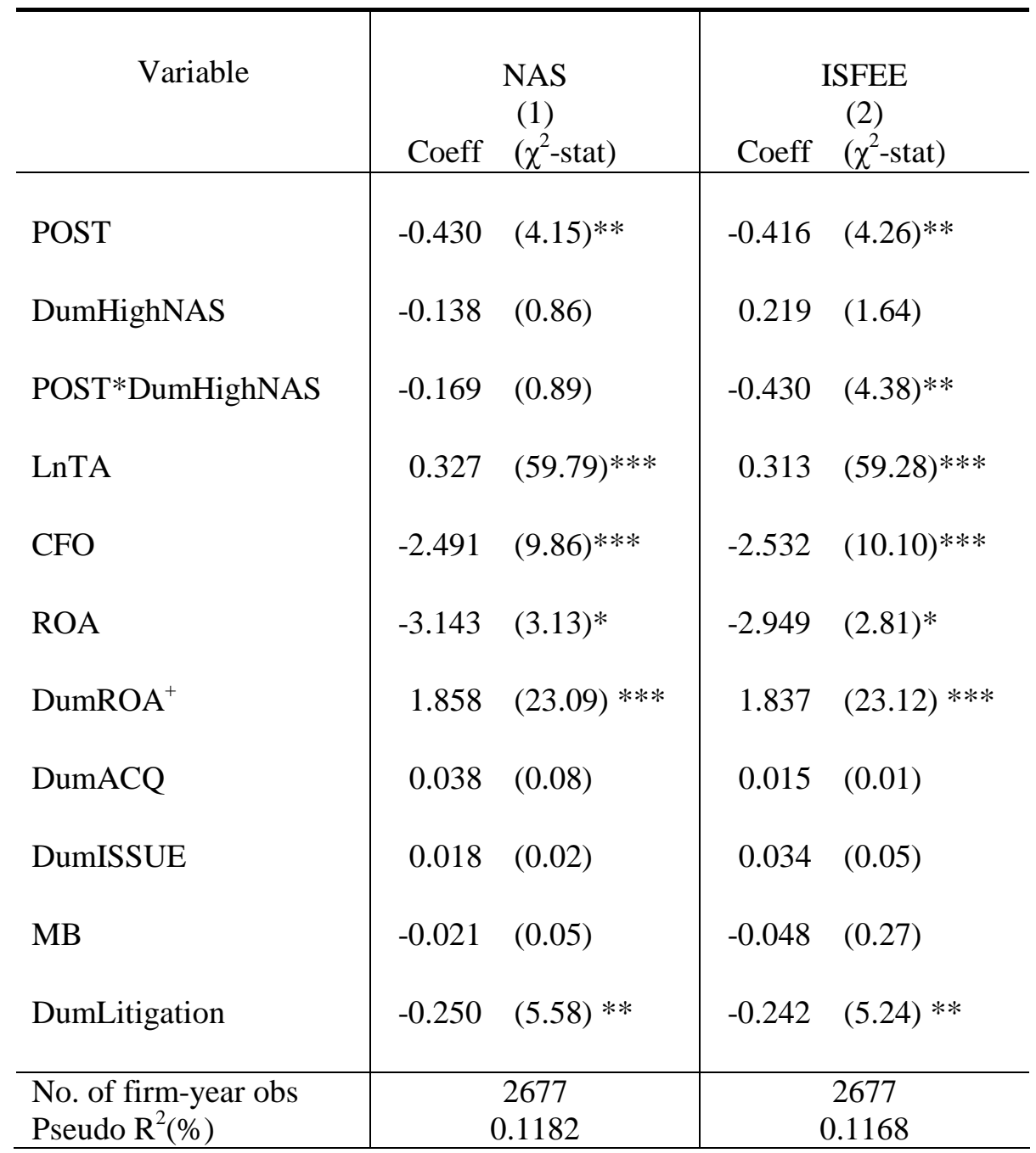


Table 6: NAS and Earnings Quality after rescission of ASR 250

\section{Panel C: NAS and Earnings Informativeness}

$$
\begin{aligned}
& \left.\operatorname{RET}_{i, t}=\beta_{0}+\beta_{1} \text { Earnings }_{i, t}+\beta_{2} \text { Earnings }_{i, t} * \operatorname{POST}_{i, t}\right)+\beta_{3}\left(\text { Earnings }_{i, t} * \operatorname{DumHighNAS}_{i, t}\right) \\
& +\beta_{4}\left(\text { Earnings }_{i, t} * \operatorname{POST}_{i, t} * \text { DumHighNAS }_{i, t}\right)+\beta_{5}\left(\text { Earnings }_{i, t} * \operatorname{LnTA}_{i, t-1}\right) \\
& +\beta_{6}\left(\text { Earnings }_{i, t} * \text { Risk }_{i, t}\right)+\beta_{7}\left(\text { Earnings }_{i, t} * \operatorname{LEV}_{i, t-1}\right)+\beta_{8}\left(\text { Earnings }_{i, t} * \text { MB }_{i, t-1}\right) \\
& +\beta_{9}\left(\text { Earnings }_{i, t} * \operatorname{VAR}_{i, t}\right)+\beta_{10}\left(\text { Earnings }_{i, t} * \operatorname{PERS}_{i, t}\right)+\gamma \text { IndustryDummies }_{i, t} \\
& +\delta \text { YearDummies }_{t}+\varepsilon_{t}
\end{aligned}
$$

\begin{tabular}{|c|c|c|c|c|}
\hline \multirow[t]{2}{*}{ Variable } & \multicolumn{2}{|c|}{$\begin{array}{l}\text { NAS } \\
(1)\end{array}$} & \multicolumn{2}{|c|}{$\begin{array}{l}\text { ISFEE } \\
\text { (2) }\end{array}$} \\
\hline & Coeff & (t-stat) & Coeff & (t-stat) \\
\hline Earnings & 0.949 & $(3.18)^{* * *}$ & 0.995 & $(3.41)^{* * *}$ \\
\hline Earnings*POST & 0.163 & $(1.81)^{*}$ & 0.187 & $(2.37)^{* *}$ \\
\hline Earnings*DumHighNAS & 0.103 & $(1.09)$ & 0.089 & $(0.84)$ \\
\hline $\begin{array}{l}\text { Earnings*POST* } \\
\text { DumHighNAS }\end{array}$ & 0.151 & $(1.38)$ & 0.125 & $(0.83)$ \\
\hline Earnings*LnTA & -0.056 & $(-1.72)^{*}$ & -0.053 & $(-1.63)$ \\
\hline Earnings*Risk & -0.150 & $(-2.24)^{* *}$ & -0.162 & $(-2.59) * *$ \\
\hline Earnings*LEV & 0.205 & $(0.60)$ & 0.110 & $(0.32)$ \\
\hline Earnings*MB & 0.103 & $(1.22)$ & 0.114 & $(1.33)$ \\
\hline Earnings*VAR & -0.065 & $(-5.50)^{* * *}$ & -0.067 & $(-5.55)^{* * *}$ \\
\hline Earnings*PERS & 0.045 & $(1.82)^{*}$ & 0.041 & $(1.56)$ \\
\hline No. of firm-year obs & & 456 & & 456 \\
\hline Adjusted R²(\%) & & 1046 & & 1021 \\
\hline
\end{tabular}

Notes: SIC2 Industry Dummies and Year Dummies are not reported for brevity. POST refers to the 3-year sample period following the rescission of ASR250. For NAS, DumHighNAS is a dummy set to 1 if the firm's last reported NAS ratio prior to the rescission of ASR250 is above the sample median. For ISFEE, DumHighNAS is a dummy set to 1 if the firm's report ISFEE prior to the rescission of ASR250. All other variables are as defined in previous tables. *, **, *** indicates significance level (2-tailed) at $10 \%, 5 \%$ and $1 \%$ respectively. 